\title{
Facies arrangement and cyclostratigraphic architecture of a shallow-marine, warm-water carbonate platform: the Late Carboniferous Ny Friesland Platform in eastern Spitsbergen (Pyefjellet Beds, Wordiekammen Formation, Gipsdalen Group)
}

\author{
Dierk Blomeier $\cdot$ Christian Scheibner $\cdot$ Holger Forke
}

Received: 27 June 2008 / Accepted: 25 September 2008 / Published online: 11 November 2008

(C) Springer-Verlag 2008

\begin{abstract}
During the Late Carboniferous, a spacious warm-water carbonate platform developed across the eastern part of the present Arctic archipelago of Svalbard. The platform initiated in the Moscovian on an uplifted fault block (Ny Friesland High) and progradated during the Late Moscovian to Early Kasimovian into the adjacent Campbellryggen Basin (central Spitsbergen). The fossiliferous platform strata are characterized by a pronounced cyclicity formed by stacked parasequences, which consist of defined, subtidal to supratidal facies-set successions reflecting a general shallowing of the depositional area. Up to 17 of these shallowing-upward cycles, bounded by distinct discontinuity (marine flooding) surfaces due to the recurrent emersion and subsequent flooding of the platform surface, have been recognized within the platform strata. The stacked cycles are the result of global, glacio-eustatic, highfrequent and high-amplitudinal sea-level fluctuations with eccentricity periodicities caused by ice volume changes during the Gondwana Land glaciation. Based on systematic changes of the cycles (thickness and internal facies
\end{abstract}

Electronic supplementary material The online version of this article (doi:10.1007/s 10347-008-0163-3) contains supplementary material, which is available to authorized users.

\section{Blomeier $(\bowtie)$}

Norwegian Polar Institute,

The Polar Environmental Centre, 9296 Tromsö, Norway

e-mail: blomeier@npolar.no

\section{Scheibner}

University Bremen, FB 5, Klagenfurter Straße 2,

PB 330440, 28334 Bremen, Germany

H. Forke

Natural History Museum of the Humboldt University Berlin, 10115 Berlin, Germany composition), the upper part of the platform strata is interpreted as a progradational parasequence set of a late highstand system tract.

Keywords Warm-water carbonate platform . Parasequence - Cyclostratigraphy $\cdot$ Carboniferous . Pennsylvanian $\cdot$ Svalbard (Spitsbergen)

\section{Introduction}

The Late Paleozoic is characterized by pronounced climatic variations, due to substantial ice-volume changes within higher-latitude areas on the southern hemisphere of Pangea (Gondwana Land glaciation; Serpukhovian-Sakmarian; Veevers and Powell 1987). The latter resulted in global eustatic sea-level fluctuations of Milankovich periodicities comprising sea-level changes of more than $100 \mathrm{~m}$ (Tucker et al. 1993; Soreghan and Giles 1999; Golonka and Ford 2000; Joachimski et al. 2006). These, in turn caused a distinct cyclicity of shallow-marine deposits, which is supposed to be a synchronous, world-wide phenomenon (Veevers and Powell 1987; Ross and Ross 1985, 1988).

The cyclic deposits of the Late Carboniferous (Late Moscovian to Early Kasimovian) Ny Friesland Platform form a substantial part of the Late Paleozoic strata on Svalbard. The latter are subdivided by numerous lithostratigraphical units, which were described and defined in earlier studies (Nathorst 1910; Gee et al. 1952; McWhae 1953; Forbes et al. 1958; Forbes 1960; Birkenmajer and Czarniecki 1960; Birkenmajer 1964) and subsequently arranged into a general lithostratigraphical scheme proposed by Cutbill and Challinor (1965). Later publications provided more detailed work on the facies of individual lithostratigraphic units in order to resolve their temporal and spatial 
development, internal arrangement, and reconstruction of the depositional environments (Lønøy 1981; Sundsb $\varnothing$ 1982; Steel and Worsley 1984; Dallmann 1993; Lønøy 1995; Pickard et al. 1996; Hüneke et al. 2001). Due to increasing improvements and a more detailed understanding, Dallmann (1999) compiled a revised and enhanced lithostratigraphic scheme of the Late Paleozoic of Svalbard.

However, the bulk of the studies addressing the Late Paleozoic limestone strata are geographically restricted to central Spitsbergen (Bünsow Land, Dickson Land). Investigations on the strata of the Ny Friesland Platform within the eastern parts of Svalbard (Cutbill 1968; Lauritzen and Worsley 1975; Lauritzen 1981a, b; Olaussen 1982) are relatively scarce, probably due to the extensive ice cover and the remoteness of the outcrop areas.

The gap is closed by this article, which provides a detailed facies analysis of the platform strata from eastern Spitsbergen. A number of vertical sections have been established and outcrop observations are combined with detailed microfacies studies.

The data are used to reconstruct a facies model displaying depositional environments, biotic associations and sedimentary processes, and the effect of relative sea-level fluctuations on the platform system. In this connection, the facies successions of the parasequences, their stacking pattern and the overall cyclicity of the platform strata are discussed.

\section{Geological setting}

The Late Paleozoic sedimentary record of Svalbard

In central and eastern Spitsbergen (Dickson Land, Bünsow Land, Ny Friesland, Olav V Land, Sabine Land) and in the south-western part of Nordaustlandet (Gustav Adolf Land), Late Paleozoic cap rocks rest with an angular unconformity on pre- to post-Caledonian basement rocks.

The Carboniferous and Permian sedimentary record in these areas is fundamentally affected by a number of major structural-geologic elements, which formed the paleogeographic framework of the depositional area.

Extensional tectonics during the Early to Late Carboniferous (Serpukhovian-Moscovian) created a series of roughly NNW-SSE-trending, elongated, narrow rift basins with half-graben geometries and adjacent highs (Steel and Worsley 1984). The reactivation of the Billefjorden Fault Zone, one of the major tectonic lineaments of Svalbard, which is supposed to have been repeatedly active during different periods in geological history (Harland 1997), led to the development of the Billefjorden Trough in central Spitsbergen (Fig. 1). To the west of the elongated basin, the Nordfjorden High remained a positive area until the Late Carboniferous. To the east, the Billefjorden Trough was bounded by another major horst structure, the Ny Friesland High, which in turn was bordered by the Lomfjorden Fault Zone (LFZ) in the east. The latter caused the formation of an albeit smaller graben, named the Lomfjorden Trough (Gjelberg and Steel 1981; Harland 1997), which was probably filled in at the end of the Early Carboniferous and formed an extended peneplain together with the Nordaustlandet High to the east and the Ny Friesland High to the west, until it was submerged and platform growth started in the Moscovian (Fig. 1).

The overall Late Paleozoic sedimentary strata of Svalbard are arranged into three major lithostratigraphic units, the Billefjorden, Gipsdalen and Tempelfjorden groups (Fig. 2).

From the uppermost Devonian (Famennian) to the Early Carboniferous (Visean), siliciclastic, non-marine sediments of the Billefjorden Group were deposited in the above-mentioned, tectonically active, possibly isolated rift basins. Under humid climatic conditions, alluvial fans built out from the horst rims into the adjacent troughs, which were marked by swamps, lakes, and vegetated, fluvial plains. Hence, deposits mainly consist of conglomerates, sandstones to shales with locally intercalated coal seams (Steel and Worsley 1984; Worsley et al 1986).

During the deposition of the overlying Early Carboniferous to Early Permian Gipsdalen Group (SerpukhovianEarly Artinskian), the depositional area of present-day Svalbard was roughly situated between the 20th and 40th northern latitude (Scotese and McKerrow 1990). The sedimentary record reflects a transition into a semi-arid to arid climate (Steel and Worsley 1984; Pickard et al. 1996; Beauchamp et al. 1989; Beauchamp 1994), accompanied by a major sea-level rise.

Sedimentation started with local terrestrial red beds, deposited in the same troughs as the sediments of the underlying Billefjorden Group. Under an increasing marine influence, the clastic deposits were gradually replaced by sabkha evaporates and shallow-marine, fossiliferous carbonate rocks. By Moscovian times, active rifting ceased and structural high areas were progressively transgressed (Johannessen and Steel 1992; Hüneke et al. 2001) while the entire depositional area underwent a more or less uniform subsidence. This development resulted in stable shelf conditions and the widespread deposition of warm-water carbonate deposits. Since then, sedimentation patterns and platform growth was mainly controlled by climatic variations in connection with relative sea-level fluctuations.

The overlying Tempelfjorden Group comprises Early to Middle/Late Permian (Late Artinskian-Kazanian/Tatarian) marine shelf deposits, which were also deposited on a stable marine shelf, but under more temperate and deeper marine conditions resulting in a uniform ramp sedimentation of fundamental different facies. 


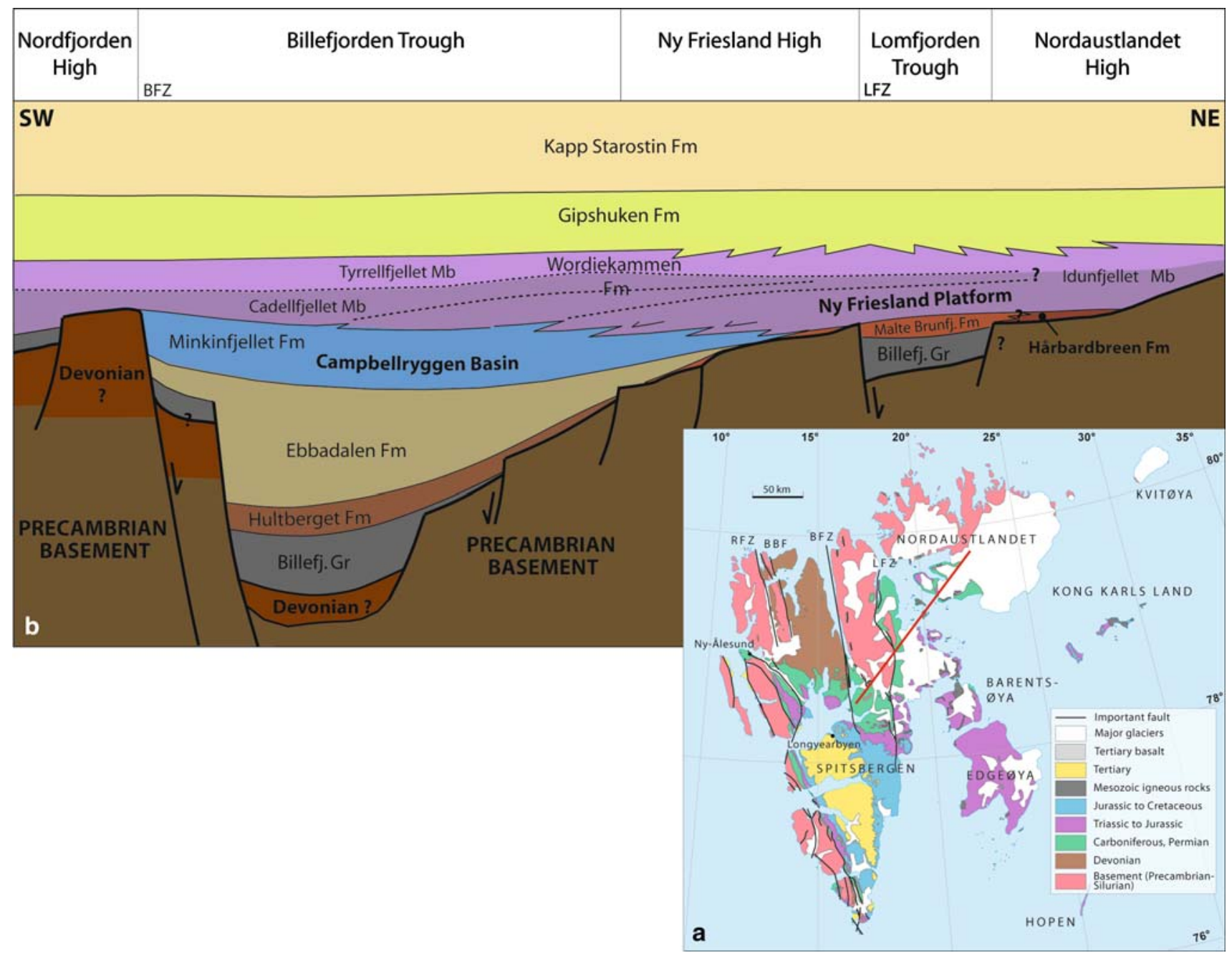

Fig. 1 Geological overview of Svalbard (a) and schematic cross section (b) through central and northeastern areas of the archipelago (roughly following the red line in a), showing the major structural-geologic elements and the configuration of the Paleozoic superstructure. Note the position of the Ny Friesland Platform (Pyefjellet Beds) pro-

Hence, mixed-siliciclastic/carbonate deposits consisting of siltstones, shales, partly glauconitic sandstones, cherts, and locally extensively silicified, fossiliferous limestones are the main lithologies of the strata, which comprise shoreface to deeper shelf environments. Contrary to the underlying warm-water deposits of the Gipsdalen Group, comprising a photozoan biotic association, the biotic assemblage of the Tempelfjorden Group resembles a heterozoan biofacies (Hüneke et al. 2001).

\section{Lithostratigraphy of the Gipsdalen Group}

While the general arrangement of the Late Paleozoic strata is still significant as originally proposed by Cutbill and Challinor (1965), the internal subdivision of the Gipsdalen Group has been substantially revised and modified to this day. Within central and eastern Spitsbergen and Nordaust- grading into the Campbellryggen Basin. LFZ Lomfjorden Fault Zone, $B F Z$ Billefjorden Fault Zone, BBF Breibogen Fault Zone, RFZ Raudfjorden Fault Zone (modified after Johannessen and Steel 1992 and Dallmann 1999)

landet the Gipsdalen Group is subdivided into various lithostratigraphical units (Dallmann 1999; Fig. 2).

In central Spitsbergen, the terrestrial red beds of the Hultberget Formation (Late Serpukhovian), which are restricted to the depositional area of the Billefjorden Trough, display the oldest lithostratigraphic unit of the Gipsdalen Group. Lithological similar successions as the Malte Brunfjellet Formation in eastern Spitsbergen (Lomfjorden Trough) and the Hårbardbreen Formation on Nordaustlandet lack detailed sedimentological and stratigraphical investigations until now. However, recent age determinations (Behrend 2007) of the Malte Brunfjellet Formation have shown that the depositional age of this formation is much older as so far suggested (BashkirianSerpukhovian instead of Moscovian) and point to a possibly coeval, similar terrestrial sedimentation within smaller, local depocenters in eastern parts of Svalbard. 


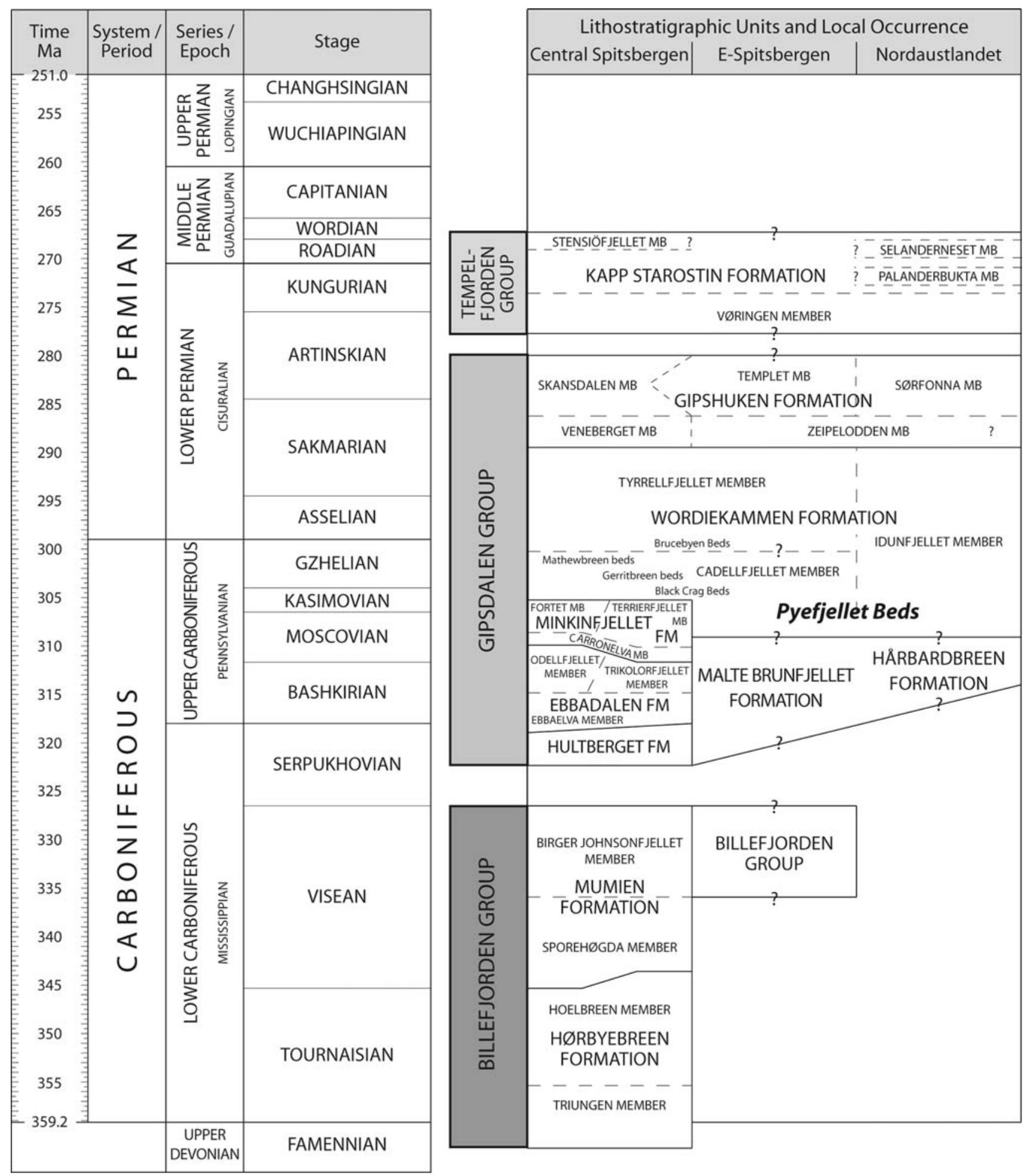

Fig. 2 Scheme of the Late Paleozoic lithostratigraphic framework of central and eastern Spitsbergen and of Nordaustlandet. Timetable modified after Gradstein et al. (2004), lithostratigraphy modified after Dallmann (1999)

Within central Spitsbergen, the Hultberget Formation is overlain by the Ebbadalen Formation (Bashkirian), which reflects the beginning of the marine transgression in this area. Highly variable rocks, consisting of siliciclastics, evaporites and carbonates were deposited within continental to marginal-marine environments comprising lakes, alluvial fans, braided rives, and river deltas but also sabkhas, lagoons, and seashore areas (Johannessen and Steel 1992). 
The overlying Minkinfjellet Formation (MoscovianEarly Kasimovian) mainly consists of interbedded carbonate (limestones and dolomites), clastic (sandstones to shales) and evaporite (gypsum) beds, which represent shallow-marine to restricted peritidal environments of the Campbellryggen Basin, a low-relief, shallow-marine basin formed within the Billefjorden Trough during this period (Pickard et al. 1996).

During the deposition of the Wordiekammen Formation (Early Moscovian-Sakmarian) local horst structures were gradually overlapped and a laterally continuous shelf sequence developed upwards in connection with the culmination of a widespread marine transgression over nearly entire Svalbard. The strata mainly consist of fossiliferous limestones, representing open- to semi-restricted shallow subtidal and restricted intertidal to supratidal depositional environments.

The following Gipshuken Formation (SakmarianArtinskian) is also supposed to be deposited over the entire archipelago, except for the southernmost part of Spitsbergen (Sørkapp-Hornsund High). The sediments, mainly composed of evaporites (anhydrite and gypsum) and carbonates (dolomite and limestone) display an extended platform characterized by a cyclic sabkha deposition (Hüneke et al. 2001).

\section{The Ny Friesland Platform}

Along the eastern margin of the Campbellryggen Basin, on the hanging wall of the Ny Friesland High, the sediments of the Minkinfjellet Formation interfinger with the limestonedominated strata of the Pyefjellet Beds, which constitute the strata of the Ny Friesland Platform. The latter were deposited contemporaneously on the neighboring horst structure and are attributed to the Cadellfjellet Member of the Wordiekammen Formation (Fig. 2). The boundary is diachronous and generally becoming younger westwards as the Pyefjellet Beds progradated to the west into the Campbellryggen Basin (Pickard et al. 1996; Dallmann 1999; Fig. 1b).

Age determinations by means of corals, chaetetids, conodonts and fusulinids (Cutbill and Challinor 1965; Nilsson 1993; Pickard et al. 1996) reveal a Late Moscovian to Early/Middle Kasimovian age of the platform strata in central Spitsbergen. Here, the sediments generally wedge out, attaining a maximum cumulative thickness of ca. $50 \mathrm{~m}$ (Bünsow Land, Gipsdalen). While the base is only poorly exposed and marked by a transition of the fossiliferous platform limestones into component-free, massive dolomites probably belonging to the Minkinfjellet Formation, the top is marked by the occurrence of the Black Crag Beds, displaying the termination of the platform growth in central Spitsbergen (Fig. 2). The Black Crag Beds (Early Kasimovian-Late Kasimovian or earliest Gzhelian), a cyclic succession mainly consisting of dark gray, massive mudstones and fossiliferous wackestones to packstones, form the lowermost part of the Cadellfjellet Member in central Spitsbergen where the platform strata are absent. With a maximum thickness of $60 \mathrm{~m}$ (Bünsow Land), the succession continuously thins to the east and is probably represented as single marker horizons intercalated within the strata of the Pyefjellet Beds.

Other subunits of the Cadellfjellet Member, which are quite distinct in central Spitsbergen (Campbellryggen Basin) and reach considerable thicknesses, like the Gerritbreen Beds and Mathewbreen Beds, seem to be missing completely in eastern Spitsbergen. Here, the Pyefjellet Beds form the substantial part of the Cadellfjellet Member, reaching an entire maximum thickness of ca. $110 \mathrm{~m}$ ("Section MB1", Malte Brunfjellet). The platform strata overlap siliciclastic red beds (Hårbardbreen Formation in Nordaustlandet, Malte Brunfjellet Formation in eastern Spitsbergen), or were deposited directly on Caledonian basement rocks of Paleozoic age ("Section C1", Carpethøgda).

The highly diverse component composition of the fossiliferous platform strata has been described as chloroforam association (Hüneke et al. 2001), reflecting a typical warmwater, shallow-marine carbonate-platform environment. The latter is characterized by a variety of carbonate-precipitating organisms consisting of various calcareous algae (green algae, red algae, phylloid algae), Palaeoaplysina, various benthic foraminifers, echinoderms, brachiopods, bryozoans, tabulate and rugose corals, mollusks as well as abiotic components like ooids and peloids.

The cyclic platform strata are characterized by up to several-meter-thick, stacked sedimentary successions, which are individually capped and bounded by distinct discontinuity surfaces. Seven of these cycles have been recognized in central Spitsbergen consisting of thin- to medium-bedded, bioclastic wackestones to packstones at the base, which are overlain by a varied phylloid algal and/or Palaeoaplysina facies, consisting of wackestones and bafflestones locally forming larger bioherms (Pickard et al. 1996). Above these, grainstones rich in beresellacean algae locally occur. The top of the individual cycles in central Spitsbergen are marked by Microcodium, paleosols and hummocky karst surfaces.

Within this study, up to 17 individual cycles have been recognized within the platform strata in eastern Spitsbergen, characterized by defined facies successions shown below.

\section{Methods}

Spitsbergen offers outstanding exposures of the Late Paleozoic strata, not only in central Spitsbergen (Dickson Land, Bünsow Land) but also in the eastern parts (Ny Friesland, Olav V Land) of the island. Here, the landscape is dissected by 
numerous, modern-day erosional valleys, canyons and fjords, where large-scale sedimentary structures and the architecture of the Ny Friesland Platform strata are superbly exposed. This excellent exposure situation enables unique opportunities for sedimentological and cyclostratigraphical investigations in combination with detailed microfacies studies.

Geological fieldwork was carried out for several weeks during July and August in the years 2004 and 2005. During these periods, the Late Paleozoic strata of eastern Spitsbergen were mapped at a scale of 1:100.000 and a number of lithostratigraphical sections were established and measured bed-by-bed in selected key localities of the mapping area. From these, four vertical sections have been chosen for this study, spanning a roughly $\mathrm{N}-\mathrm{S}$-trending transect of around $110 \mathrm{~km}$ in length (Fig. 3).

In order to resolve the facies arrangement of the single cycles and overall cyclostratigraphic architecture of the $\mathrm{Ny}$ Friesland Platform, large-scale stacking patterns, colors, lithologies, textures, sedimentary structures, and the fossil content of the sediments were documented in all sections.

Outcrop investigations were combined with detailed microfacies studies. Hence, a total number of 531 (C1: 118; MB1: 187; L1: 181; D2: 47) over-sized thin sections $(7.5 \times 10 \mathrm{~cm}$ to $5 \times 5 \mathrm{~cm})$ were used to investigate the compositional variation of the limestone beds of all vertical sections. Following previous quantitative microfacies studies by point counting (Hülse 2007; Reinicke 2006), a semiquantitative frequency analysis of the investigated sections were applied. As a result, 22 different skeletal and non-skeletal grain types were distinguished and assigned into four main microfacies groups (Table 1).

\section{Facies analyses}

Platform strata of the vertical sections

\section{Section L1}

The northernmost vertical section is located at the eastern coast of Lomfjorden (Mjølnerfjellet; Fig. 3) and comprises a 83-m-thick platform succession, which is exposed within a cliff wall along the coast (Fig. 5a, b). At the base of the escarpment the platform strata, which mainly consist of very thick- to medium-bedded limestones and dolomites with subordinate, thin-bedded marls to marly claystones, rest on siliciclastic red beds of the Malte Brunfjellet Formation, although the direct transition is covered by scree.

The cyclic platform strata are arranged into 12 stacked cycles (Fig. 4), which show a generally decreasing thickness upward, from maximum ca. $17 \mathrm{~m}$ in the lower part to minimum ca. $2 \mathrm{~m}$ in the upper part of the entire sedimentary succession. Cycles from the lower part of the succession (cycles
$1,3,4)$ often exhibit thin, marl and claystone interbeds and grayish medium-bedded limestones, locally marked by the occurrence of horn-shaped, solitary rugose corals at their base. Further up in strata, the individual cycles are mainly formed of very thick- to thick-bedded limestone beds often marked by stylolites and locally comprising siliceous concretions, as well as partly highly cavernous dolomite beds. The sharp boundaries at the top of the single cycles are often marked by distinct red stainings.

\section{Section C1}

The platform succession at Carpethøgda ("Section C1"; Figs. 3, 4) shows an overall thickness of $61 \mathrm{~m}$ and unconformably rests on Caledonian granitic basement rocks (Fig. 5c). The base of the platform strata is marked by a thin weathering horizon, consisting of immature, normalgraded, calcareous gravelstones to sandstones (Fig. 5d). The latter contains the erosional reworking products of the basement rocks (mainly angular quartz clasts), which were redeposited during the transgression of the granitic horst structure as well as varied marine biota of the platform (e.g., fusulinids, mollusks, corals).

The platform strata above, mainly formed of grayish, yellowish and reddish, thick- to medium-bedded limestone and dolomite beds is marked by a pronounced cyclicity consisting of altogether 17 stacked cycles with thicknesses between 7 (cycle 8 ) and $1 \mathrm{~m}$ (cycle 11). Cycle boundaries are generally characterized by conspicuous color and facies changes of the sedimentary strata, often accompanied by the occurrence of thin, distinct red mudstone or lithoclastic horizons or lenses. The relatively little average thickness of the stacked cycles and dominance of microfacies types representing platform interior and sabkha zones point to the existence of a geomorphological high area of the platform within this location.

\section{Section D1}

At Ditlovtoppen ("Section D1"; Figs. 3, 4), Late Paleozoic cap rocks are deposited with an angular unconformity on Precambrian basement rocks (Neoproterozoic Dracoisen and Wilsonbreen formations of the Polarisbreen Group; Halverson et al. 2004). The base of the superstructure is formed of siliciclastic, terrestrial sandstones to silty claystones of the Billefjorden Group, representing fluvial and alluvial plain deposits marked by the local intercalation of coaly, organic-rich horizons and lenses (Fig. 5e). The sedimentary strata is overlain by a red-bed succession belonging to the Malte Brunfjellet Formation. The latter mainly consist of poorly exposed, greenish, reddish and yellowish claystones interbedding with thick-bedded, massive dolomite beds at different levels, probably representing marginal 
Fig. 3 Geological overview map of the investigation area, including the positions of the logged sections along the Lomfjorden Fault Zone in eastern Spitsbergen

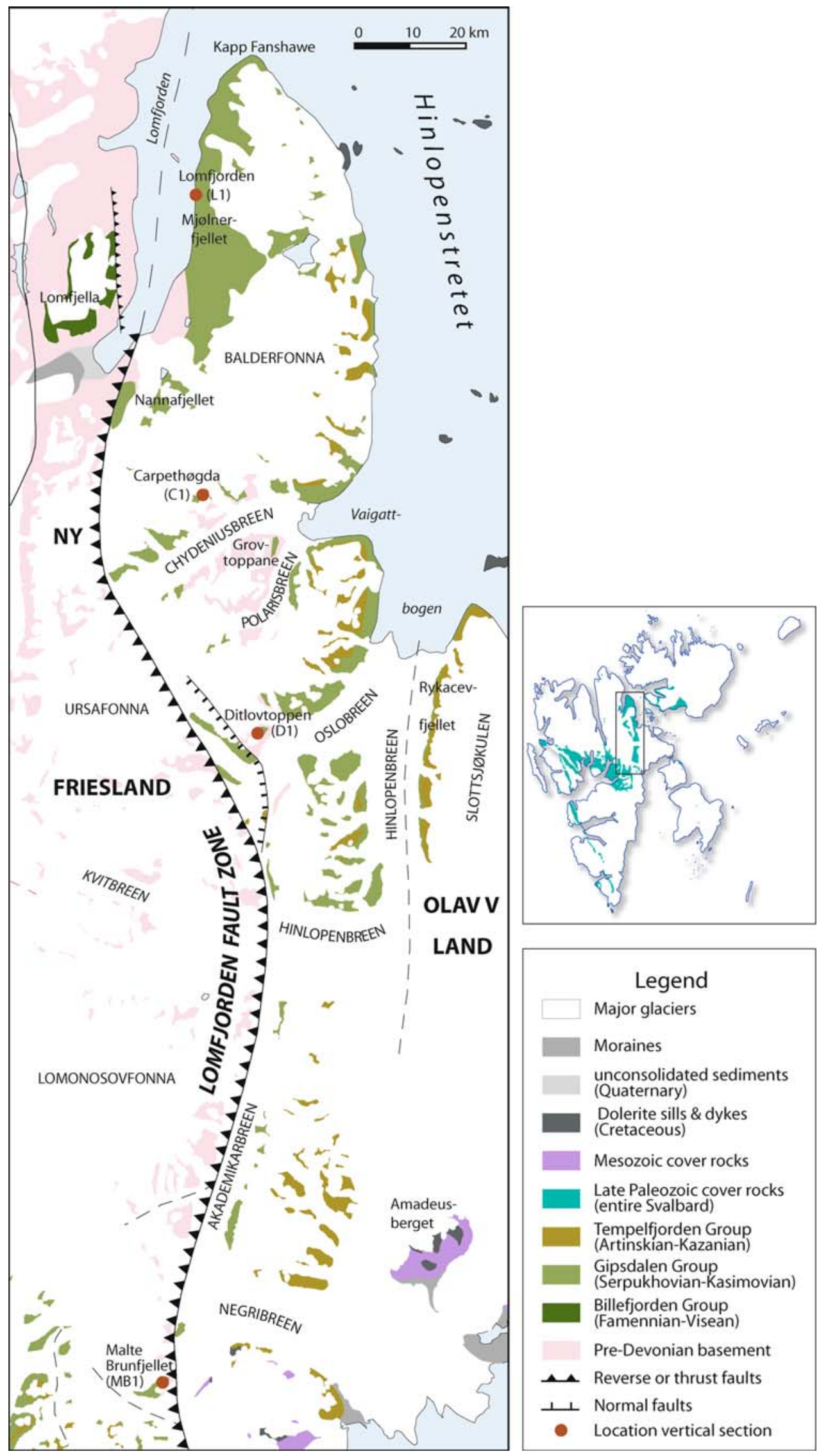


Table 1 Matrixes and component types of the Ny Friesland Platform

\begin{tabular}{ll}
\hline Component group & Matrix/grain types \\
\hline Matrixes & Micrite/microsparite, calcite cements \\
Skeletal grains & Arthropoda: Trilobites, ostracodes \\
& Brachiopoda (impunctate, pseudopunctate, punctuate) \\
& Bryozoa (fenestellidae, fistuliniporidae, ramosae) \\
& Calcareous algae: Coralline red, beresellid green, phylloid algae \\
& Corals: Rugosa, Tabulata \\
& Echinodermata (crinoids, echinoids) \\
& Foraminifera: Fusulinids (Neostafella, Beedeina, Pseudofusulinella, \\
& Ozawainella, Fusiella, Schubertella), small foraminifers \\
& (encrusting, Bradyina, Pseudoendothyra, Tetrataxis, \\
& Palaeotextulariidae, Globerina, Tuberitina) \\
& Mollusks (gastropods, bivalves) \\
& Problematica: Chaetitids, palaeoaplysinids, Shamovella (Tubiphytes), Microcodium \\
& Lithoclasts (intraclasts, autoclasts), ooids (altered, micritic-radial fibrous), peloids \\
& Rock and mineral fragments \\
& Mineral separations (dolomite, Fe-minerals, pyrite, insoluble residue) \\
\hline Non-skeletal grains &
\end{tabular}

marine deposits formed during the initial transgression of the depositional area.

These deposits in turn are conformably overlain by a 42-m-thick, cyclic limestone succession of the Ny Friesland Platform, arranged in altogether ten stacked cycles of medium- to thick-bedded limestones and dolostones (Fig. 5f).

\section{Section $M B 1$}

The southernmost outcrop at Malte Brunfjellet ("Section MB1"; Figs. 3, 4) yields a ca. 110-m-thick platform succession, which concordantly rests on the strata of the Malte Brunfjellet Formation (Fig. 5g). The latter in turn forms an angular unconformity to the underlying Neoproterozoic basement rocks of the Dracoisen Formation (Polarisbreen Group). While the lowermost, ca. 13-m-thick part of the Malte Brunfjellet Formation comprises a typical terrestrial succession, consisting of intensively Fe-stained, fluvial sandstones and finer-grained flood plain deposits, the uppermost part, which is separated by a ca. 30-m-thick succession covered by scree, shows a completely different facies. The latter is formed by an interbedding of thin- to medium-bedded caliche horizons and medium- to thick-, often cross-bedded, clastic breccias to coarse sandstones (Behrend 2007). This ca. 16-m-thick succession has been interpreted as fluvio-marine deposits (Miloslavskij et al. 1998), and represents a gradual transition into the full marine platform setting of the Ny Friesland Platform due to a progressive marine transgression.

The overlaying platform strata, mainly consisting of massive limestones and dolostones, are arranged into 17 stacked cycles showing thicknesses from 12 (cycle 11) to $2 \mathrm{~m}$ (cycle 14). This section solely comprises larger Palaeoaplysina buildups (Palaeoaplysina mound facies, microfacies type 15) of up to a few meters in thickness (cycle 11).

\section{Microfacies analysis}

In total, 15 different microfacies types (MFTs), arranged into three groups (non-biotic, bioclastic, reefal) are defined and distinguished within the carbonates (limestones and dolostones) of the cyclic platform strata (Table 2).

Each MFT, its occurrence, and association with other MFTs is described and the significance for an environmental interpretation is discussed.

\section{Non-biotic facies}

The microfacies within this group can be attributed mainly to mechanical or geochemical sedimentary processes and originates only to a minor amount directly from the presence of carbonate-precipitating organisms. Hence, the MFTs of this group are mainly composed of non-skeletal grains (lithoclasts, peloids, and ooids). Bioclasts in higher amounts solely occur within MFT 1.

It is also characteristic that most MFTs listed within this group occur either at the very base (transgressive resediments) or at the top (caliche facies, Microcodium facies, dolostones, peloidal facies, ooidal facies) of the cycles.

\section{MFT 1: transgressive resediments}

Description: This MFT mainly comprises multicolored, generally coarser-grained limestones (peloidal, litho to bioclastic rudstones to packstones), as well as locally occurring mixed-siliciclastic/calcareous sediments (calcareous gravelstones to sandstones). The more common peloidal, 
Fig. 4 Sedimentary $\operatorname{logs}$ of the Ny Friesland Platform comprising facies, microfacies types and the cyclostratigraphic arrangement of the sedimentary successions. The position of the logs is marked in Fig. 3, legend in

Fig. 12. For details in this figure see the electronic supplementary material
Section MB1

\section{Section L1}

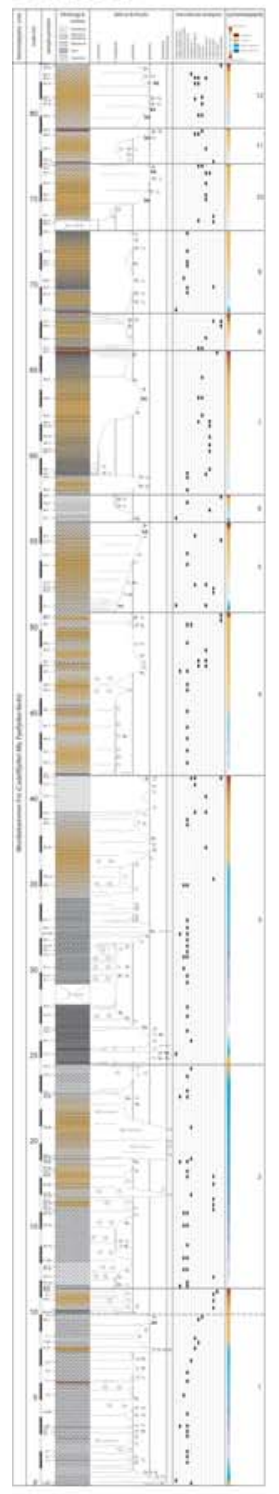

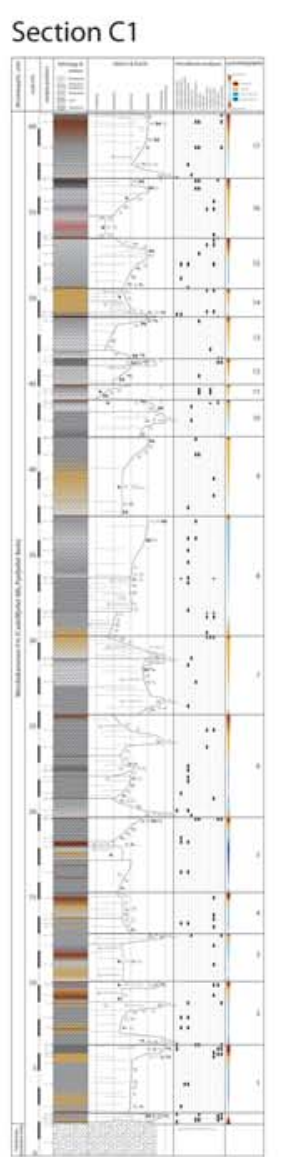

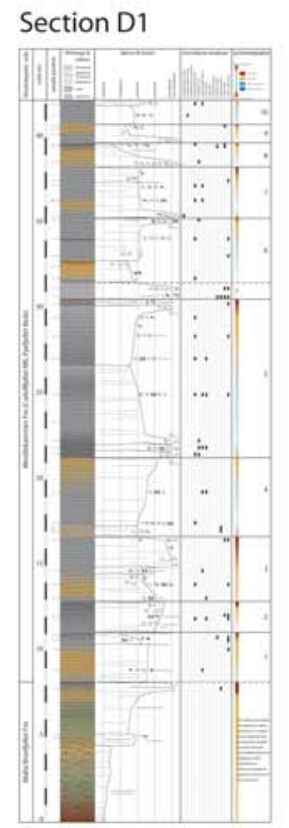

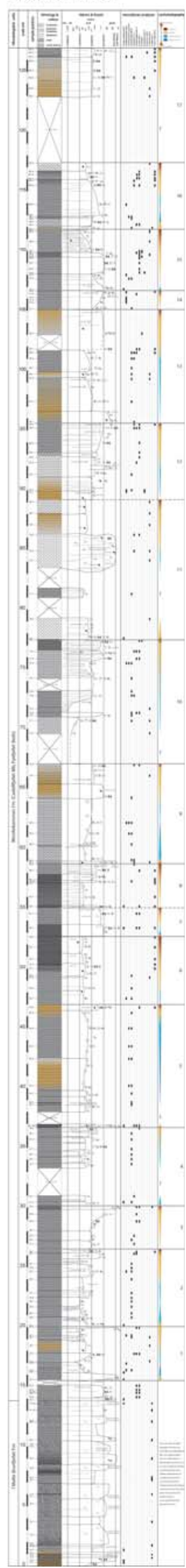




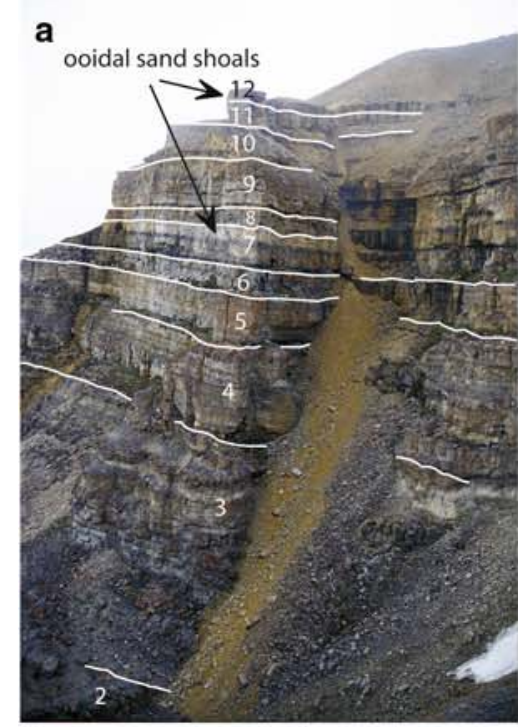

b
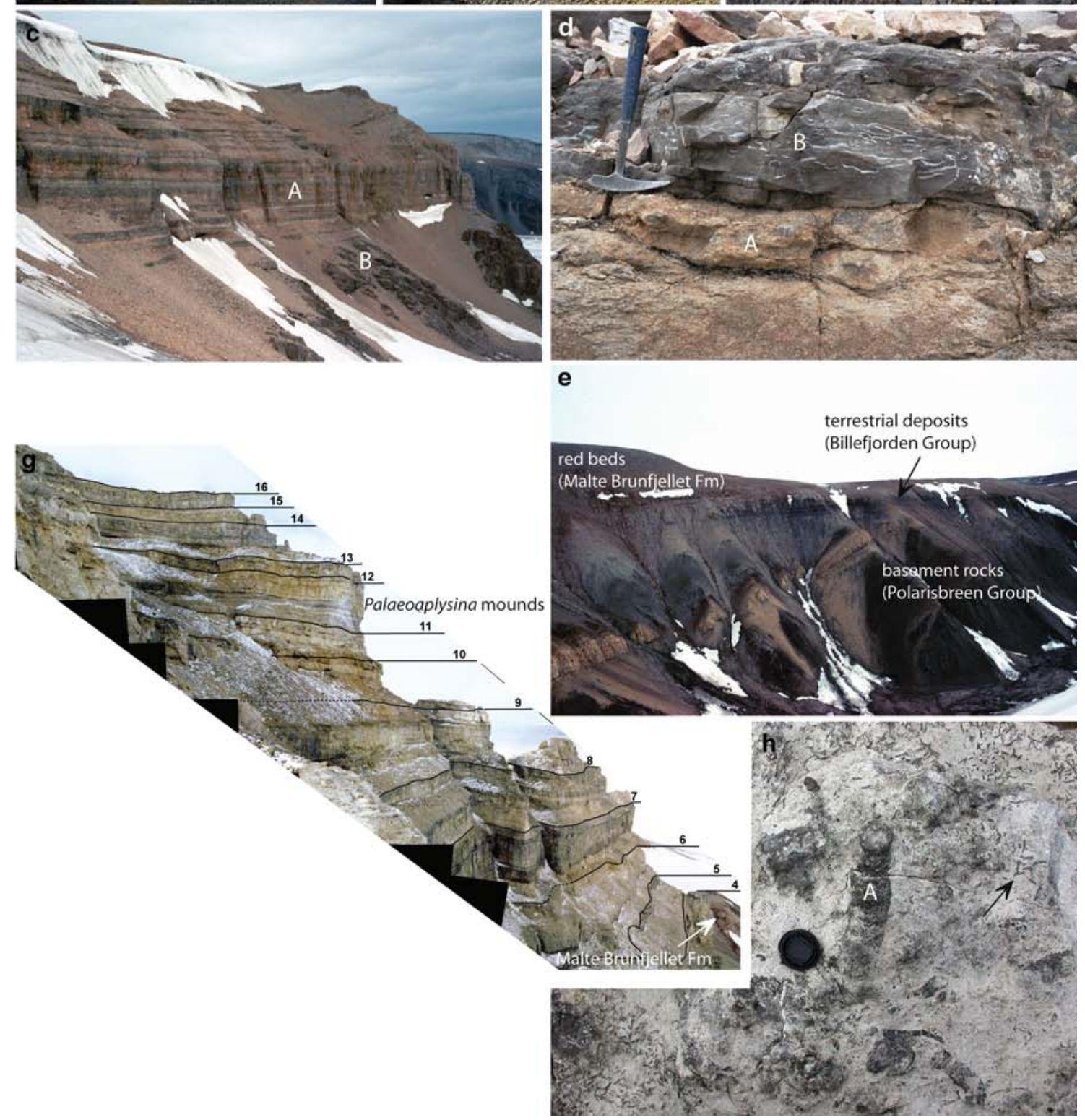
4 Fig. 5 Outcrop pictures. a Overview of the "Section L1" at Mjølnerfjellet (E-coast of Lomfjorden) comprising the cycles 2-12. A general thinning upward of the single parasequences is apparent. b "Section L1" The terrace-like geomorphology of the platform outcrops often reflects the stacking pattern of the platform strata into the recurrent parasequences (here cycles 4-7). c At Carpethøgda ("Section C1"), the bedded platform strata $(A)$ rest directly on Caledonian basement rocks $(B)$. In this location, the platform is marked by the common appearance of red, yellowish and grayish limestones and dolomites. $\mathbf{d}$ The platform onlap on the basement rocks at Carpethøgda is marked by a weathering horizon formed by calcareous sand to gravelstones $(A$, sheet 3 in Fig. 4). Above this horizon, partly sandy limestones, comprising darker caliche horizons abruptly occur ( $B$, sheet 4 in Fig. 4). e At Ditlovtoppen ("Section D1"), fluvial deposits of the Billefjorden Group form a sharp angular unconformity on Precambrian basement rocks. Above this basal succession, red beds of the Malte Brunfjellet Formation are concordantly deposited, which in turn are overlain by the strata of the Ny Friesland Platform forming the cap rocks of the Late Paleozoic superstructure. f This complete parasequence at Ditlovtoppen ("Section D1", cycle 5), shows darker gray limestones at the base grading up into lighter gray limestones and dolomites (compare to Fig. 4). g Overview of the cyclic platform strata on Malte Brunfjelllet ("Section MB1"). Note the reddish-colored, terrestrial deposits of the Malte Brunfjellet Formation in the lower right corner of the picture. $\mathbf{h}$ "Section MB1": At the base of individual cycles, intermediate-bedded limestones locally show an association of biogens and coarse bioclasts of horn-shaped, solitary corals $(A)$ and abundant filigree bryozoans (arrow), representing muddy sea flats of the mid-platform

litho to bioclastic rudstones (peloidal intrabiomicrites) show a wide range of skeletal fragments, which are present in strongly varying amounts together with lithoclasts, Microcodium crystals or aggregates and peloids (Fig. 6a). The poorly sorted, arenitic to ruditic biotic components consist of different foraminifers, often including fusulinids (staffellid foraminifers, Fusulinella, Protriticites) but also small-foraminifers and fragments of corals, brachiopods, bryozoans, and echinoderms. Partly reddish-stained peloids and up to a few centimeters large, edge-rounded to wellrounded intraclasts showing internal mudstone or peloidal to bioclastic wacke to packstone (float to rudstone) fabrics, are embedded in a heterogeneous, micritic to microsparitic matrix with grayish, reddish or brownish colors.

Calcareous, normal graded gravelstones to sandstones are characterized by significant amounts of granular- to sand-sized, angular quartz grains and rock fragments (Fig. 6b). The clasts, embedded in a heterogeneous, partly clotted, micritic matrix, form a component-supported fabric. Occasional to rare occurring peloids, lithoclasts, and skeletal fragments (mainly fusulinids, molluscs, brachiopods) form secondary constituents of this locally occurring microfacies type.

Occurrence and associations: The occurrence of transgressive resediments is restricted to the base of individual cycles of the platform strata. Normal graded gravelstones to sandstones exclusively occur at the base of the entire platform succession at Carpethøgda ("Section C1"), forming an up to a few decimeters-thick weathering horizon on the Paleozoic granitic basement rocks, together with the smallforaminifer, peloidal, Microcodium and caliche MFTs. The more common peloidal, litho to bioclastic rudstones to packstones locally form horizons or lenses of medium- to thin-bedded limestones at the base of individual cycles within all sections. Due to a changing composition of the biotic assemblage combined with a general decrease of the non-biotic components, these sediments commonly grade up into mixed-bioclastic, brachiopod/bryozoan or fusulinidforaminifer MFTs.

Interpretation: Multicolored, coarse-grained limestones from the base of individual cycles are interpreted as intraformational lag deposits formed during the repeated transgression of the formerly emerged platform surface. The highly diverse deposits contain sediment material from two different sources. Erosional products (e.g., subaerially altered intraclasts and skeletal fragments) originating from the upper part of the underlying cycle reflect a pre-existing, already lithified platform surface, which was eroded, reworked and redeposited with the subsequent flooding. These reworking products mixed with newly produced sediment material originating from the skeletal fragments of biota, which colonized the sea floor during the transgression.

The calcareous sandstones to gravelstones at the base of the vertical section at Carpethøgda ("Section C1") display the transgressive reworking products of the granitic basement, the platform strata are deposited on.

\section{MFT 2: mudstones}

Description: This MFT basically consists of very finegrained, partly silty and generally component-poor deposits, mainly comprising gray but also reddish or yellowish mudstones and minor wackestones. The deposits are preferably formed of micrite or microsparite with varying amounts of silt-sized quartz grains. The deposits are mainly massive, but occasionally show a nodular fabric or wavyhorizontal to flaser lamination due to the accumulation of the angular quartz grains in thin layers or horizons. Scattered components, mainly consisting of arenitic echinoderm or brachiopod fragments, single Microcodium crystals, peloids or ostracodes are embedded in an often slightly recrystallized, microsparitic matrix (Fig. 6c, d). Occasionally, isolated, euhedral dolomite crystals occur. In contrary to silty mudstones assigned to the caliche MFT, these generally show less secondary structures like cracks, brecciation or Fe-staining.

Occurrence and associations: Mudstones mainly occur in the lower or upper parts of individual cycles. Within the lower part, nodular or fine-laminated mudstones are associated with wackestones of the brachiopod/bryozoan facies 
Table 2 Characteristics, occurrence, and environmental reconstruction of the microfacies types of the Ny Friesland Platform

\begin{tabular}{|c|c|c|}
\hline $\begin{array}{l}\text { Microfacies } \\
\text { types }\end{array}$ & Facies/occurrence and associations & $\begin{array}{l}\text { Sedimentary processes/ } \\
\text { depositional environments }\end{array}$ \\
\hline
\end{tabular}

Non-biotic
facies

facies resediments

2 Mudstones

3 Dolostones

4 Peloidal facies

5 Ooidal facies

6 Microcodium facies

7 Caliche facies
Local, highly varied, poorly sorted, peloidal, litho to bioclastic packstones (rudstones) and calcareous, normal graded gravelstones to sandstones. Comprise a mixture of pre-existing as well as newly produced sediment material

If present, at the base of the entire platform strata and at the base of individual cycles, grading into MFTs 8, 9, 10

Consist mainly of micrite (microsparite). Wavy-horizontal to flaser bedding due to local accumulations of silt-sized quartz grains. At the top of the parasequences, laterally and vertically grading into MFTs 3, 6, 10 or 12 . At the base, associated with MFT 9 or locally interbedding with marl or claystone horizons

Original fabric is replaced by subhedral to euhedral dolomite crystals commonly forming an equi-granular texture. Multi-colored and highly porous rocks. Common in the upper part of the cycles. Associated with MFTs 4, 6, 7, 11, 13

Low-diverse, densely packed, well-sorted, fine-arenitic, peloidal grainstones to packstones. Peloids probably mainly originate from the abrasion of encrusting organisms (foraminifers, Schamovella). Common in the uppermost part of the cycles, with transitions into the MFTs 5, 6, 11, 13-15

Low-diverse, well-sorted, arenitic, ooidal grainstones to packstones are marked by the accumulation of radial-fibrous, micritic or altered ooids with bioclasts, peloids or lithoclasts in minor amounts. Occur rarely in the middle/upper part of individual cycles and are associated with MFTs 4 and 11

Single, light-brownish, equant to bladed, sparry calcite crystals, partly grouped into smaller, round to half-round aggregates or larger mats or crusts. Autochthonous mats or crusts replace primary marine deposits; allochthonous crystals and smaller aggregates are incorporated within the sediments. At the top of individual cycles within irregular cracks, root traces, patches, lenses, and thin horizons, associated with MFTs 4, 7, 11, 13-15

Red or multicolored mudstones, lithoclastic float to rudstones and varied, poorly sorted, peloidal, litho to bioclastic pack to rudstones (wacke to floatstones). Commonly marked by Fe-staining, alteration, recrystallization, dissolution and pedo-genesis. At the top of individual parasequences, associated with MFTs 3, 4, 6, 10, 11, 13
Contain the erosional products from formerly lithified, underlying platform strata or basement rocks

Deposited (1) during the transgression of the basement with the initiation of the platform or (2) during or shortly after the repeated flooding of the platform surface at the base of individual platform cycles

At cycle base, mudstones formed during or subsequent to the flooding of the platform surface. At cycle top, they represent deposition within protected, possibly restricted-marine, quiet-water areas of lagoons or on tidal flats in sub to intertidal areas of the platform interior

Secondary dolomitization of the original carbonate rocks probably occurred during early diagenesis within shallow burial depths in connection with the emersion of the platform surface

Fine-grained deposits of sandy flats, which originate from the disintegration of encrusting organisms. Under moderate energy conditions, reworking due to tidal currents or wave action within shallow subtidal to intertidal areas of the platform interior

The MFT represents low-diverse sand shoals or bars, which formed under agitated and supersaturated water conditions within shallow subtidal to intertidal lagoonal or foreshore areas of the platform interior

As a root-related feature, $M$. reflects the development of palaeosols during subaerial exposure of the platform surface. Autochthonous $M$. signals the cessation of marine conditions and a terrestrial setting. Allochthonous $M$. implies the reworking of palaeosols and the subsequent transport and redeposition of the disintegration products within coeval submerged areas of the platform interior

Indicates cessation of marine conditions. During emergence, partly brecciated mudstones form lateral discontinuous dust plates, hardpans or crusts. Litho to bioclastic pack to rudstones form capping beds/immature palaeosol horizons, due to alteration of emerged marine platform strata under semi-arid climatic conditions (sabkha) 
Table 2 continued

\begin{tabular}{|c|c|c|c|}
\hline \multicolumn{2}{|l|}{$\begin{array}{l}\text { Microfacies } \\
\text { types }\end{array}$} & \multirow{2}{*}{$\begin{array}{l}\text { Facies/occurrence and associations } \\
\text { Bioclastic packstones to wackestones, marked by } \\
\text { fusulinid foraminifers, besides fragments of } \\
\text { bryozoans, brachiopods or echinoderms. Bioturbation } \\
\text { often obliterates an indistinct primary horizontal } \\
\text { lamination. Occurs within medium-bedded limestones } \\
\text { from the lower part of the cycles with gradual lateral and } \\
\text { vertical transitions into MFTs } 9,10 \text {. Fusulinids also } \\
\text { occur within the MFTs } 1,7,13-15\end{array}$} & \multirow[b]{2}{*}{$\begin{array}{l}\text { Sedimentary processes/ } \\
\text { depositional environments } \\
\text { Represents deposition on muddy } \\
\text { flats below the mean fair-weather } \\
\text { wave base in the deeper subtidal } \\
\text { of the mid-platform, where fusulinids } \\
\text { of the geni Beedeina, Neostaffella, } \\
\text { and Wedekindellina were particularly } \\
\text { common. Fusulinid associations of } \\
\text { Fusulinella/Protriticites and staffellid } \\
\text { foraminifers also occur within } \\
\text { intertidal to shallow subtidal areas } \\
\text { of the platform interior }\end{array}$} \\
\hline $\begin{array}{c}\text { Bioclastic } \\
\text { FACIES }\end{array}$ & $\begin{array}{l}8 \text { Fusulinid- } \\
\text { foraminifer } \\
\text { facies }\end{array}$ & & \\
\hline & $\begin{array}{l}9 \text { Brachiopod/ } \\
\text { bryozoan } \\
\text { facies }\end{array}$ & $\begin{array}{l}\text { Poorly to moderate-sorted wackestones (floatstones) } \\
\text { with pre-dominance of fragments and biogens of fenestellid, } \\
\text { fistuliporid or ramose bryozoans and impunctate, } \\
\text { pseudopunctate, punctate brachiopods. An indistinct } \\
\text { wavy-horizontal to flaser bedding is often obliterated } \\
\text { by bioturbation. Mainly in cycles from the lower part } \\
\text { of the platform strata, gradual changes into MFTs } 8,10\end{array}$ & $\begin{array}{l}\text { Reflects a low-energy, open-marine } \\
\text { environment within the deeper } \\
\text { subtidal below the mean FWWB of } \\
\text { the mid-platform. The depositional } \\
\text { area was marked by low-relief, muddy } \\
\text { flats with oxygenated sea bottom } \\
\text { conditions, populated by a low-diverse } \\
\text { fauna consisting mainly of brachiopods, } \\
\text { bryozoans, echinoderms, and foraminifers }\end{array}$ \\
\hline & $\begin{array}{l}10 \text { Mixed- } \\
\text { bioclastic } \\
\text { facies }\end{array}$ & $\begin{array}{l}\text { Poorly to moderate-sorted, mainly highly diverse arenitic } \\
\text { wacke to packstones (float to rudstones), which show a } \\
\text { strongly varying component composition without the } \\
\text { predominance of any component types. No specific } \\
\text { position within the stacked cycles, associated with } \\
\text { MFTs } 8,9,11,13-15\end{array}$ & $\begin{array}{l}\text { Represents no specific depositional } \\
\text { environment. MFT formed on both, } \\
\text { submarine flats of the mid-platform } \\
\text { and in open-marine areas (flats) of the } \\
\text { platform interior, where waves } \\
\text { and currents were insufficient to } \\
\text { remove the fine-grained muddy matrix }\end{array}$ \\
\hline & $\begin{array}{l}11 \text { Small- } \\
\text { foraminifer } \\
\text { facies }\end{array}$ & $\begin{array}{l}\text { Moderate- to well-sorted, fine-arenitic bio biopeloidal } \\
\text { grainstones (packstones) marked by high amounts of } \\
\text { benthic and encrusting small foraminifers, fragments of } \\
\text { Schamovella as well as peloids and echinoderm fragments. } \\
\text { Occurs in the upper part of the cycles, } \\
\text { grading into MFTs } 4,6,13-15\end{array}$ & $\begin{array}{l}\text { The facies represents low-diverse, } \\
\text { fine-arenitic foraminiferal/peloidal } \\
\text { sand shoals within intertidal to } \\
\text { shallow-submarine areas of the } \\
\text { platform interior. Under moderate } \\
\text { energy conditions, the deposits } \\
\text { were associated with small } \\
\text { reefal structures }\end{array}$ \\
\hline & $\begin{array}{l}12 \text { Echinoderm } \\
\text { facies }\end{array}$ & $\begin{array}{l}\text { Low-diverse, moderately sorted, arenitic wackestones } \\
\text { (rare floatstones) and minor packstones, characterized } \\
\text { by a predominance of mainly medium to coarse sand-sized } \\
\text { fragments of crinoids and echinoids. In the uppermost } \\
\text { parts of single cycles associated with MFTs } 2,3\end{array}$ & $\begin{array}{l}\text { Reflects protected lagoonal or tidal flat, } \\
\text { quiet-water areas in the intertidal } \\
\text { zone marked by restricted marine } \\
\text { conditions. The occurrence of } \\
\text { low-diversity echinoderm } \\
\text { associations points to a stressed } \\
\text { environment probably due to } \\
\text { strongly changing salinity, } \\
\text { oxygenation and temperature }\end{array}$ \\
\hline $\begin{array}{l}\text { ReEFAL } \\
\text { FACIES }\end{array}$ & $\begin{array}{l}13 \text { Coral reefal } \\
\text { facies }\end{array}$ & $\begin{array}{l}\text { Consists of (1) the accumulation of solitary, horn-shaped, } \\
\text { rugose corals, which predominantly appear in the lower } \\
\text { part of individual sequences, (2) smaller biostromes mainly } \\
\text { formed by colonial tabulate and rugose corals } \\
\text { (coral bafflestones) and poorly to moderate sorted, bioclastic } \\
\text { floatstones (rudstones) in interspaces and the vicinity of } \\
\text { the biostromes. Mainly present in the middle to upper parts } \\
\text { of the cycles, associated with the MFTs } 4,6,10,11\end{array}$ & $\begin{array}{l}\text { Coral meadows (enrichment of solitary } \\
\text { rugose corals) represent local, } \\
\text { low-diverse communities formed } \\
\text { under open-marine, quiet-water } \\
\text { conditions on muddy sea flats } \\
\text { within the deeper subtidal, generally } \\
\text { below the mean FWWB of the } \\
\text { mid-shelf. } \\
\text { Small, highly diverse, flat-topped coral } \\
\text { knobs formed of chaetetids, colonial } \\
\text { rugose and tabulate corals were } \\
\text { more common within shallow } \\
\text { submarine to intertidal areas of } \\
\text { the platform interior, generally } \\
\text { above the mean FWWB }\end{array}$ \\
\hline
\end{tabular}


Table 2 continued

\begin{tabular}{|c|c|c|}
\hline $\begin{array}{l}\text { Microfacies } \\
\text { types }\end{array}$ & Facies/occurrence and associations & $\begin{array}{l}\text { Sedimentary processes/ } \\
\text { depositional environments }\end{array}$ \\
\hline $\begin{array}{l}14 \text { Algal mound } \\
\text { facies }\end{array}$ & $\begin{array}{l}\text { Autochthonous structures or the rock-forming } \\
\text { accumulation of fragments of coralline red } \\
\text { algae, dasycladalean green algae and phylloid } \\
\text { algae are generally rare. Red algae form } \\
\text { low-diverse, densely packed, bioclastic } \\
\text { packstones (rudstones); beresellid green algae } \\
\text { form low-diverse, autochthonous bafflestones; } \\
\text { poorly preserved phylloid algae form low-diverse, } \\
\text { autochthonous boundstones. Algae deposits are } \\
\text { associated with the MFTs } 10,11,13 \text {, in which the } \\
\text { fragments occur also in minor amounts }\end{array}$ & $\begin{array}{l}\text { Small algae mounds were present } \\
\text { within open-marine areas marked } \\
\text { by agitated, moderate to higher-energy } \\
\text { conditions around the FWWB, probably } \\
\text { in a transitional position between } \\
\text { deeper mudflats of the mid-platform } \\
\text { and protected and/or restricted areas of } \\
\text { the platform interior. } \\
\text { Coralline red algae and dasycladalean } \\
\text { algae were also present within coral } \\
\text { knobs of the platform interior }\end{array}$ \\
\hline $\begin{array}{l}15 \text { Palaeoaplysina } \\
\text { mound facies }\end{array}$ & $\begin{array}{l}\text { Larger Palaeoaplysina bioherms with thicknesses } \\
\text { of up to a few meters occur solely in the MB1 } \\
\text { section and comprise highly porous and locally } \\
\text { strongly dolomitized and silicified, loose framestones } \\
\text { marked by elongated, up to 2-mm-thick, sub-parallel } \\
\text { stacked plates with an internal tubular structure. } \\
\text { At the flanks of the buildups, Palaeoaplysina } \\
\text { rudstones grade into MFTs } 4,6,10,11\end{array}$ & $\begin{array}{l}\text { Palaeoaplysina buildups show a specific } \\
\text { palaeogeographic distribution along } \\
\text { the platform margin at the transition } \\
\text { into the adjacent Campbellryggen Basin. } \\
\text { Here, the organisms formed large bioherms, } \\
\text { which probably acted as an effective barrier } \\
\text { system (platform rim) during low sea-level } \\
\text { stands, protecting the platform surface } \\
\text { from more open-marine, higher } \\
\text { energetic conditions }\end{array}$ \\
\hline
\end{tabular}

(MFT 9) and locally interbed with thin marl and claystone horizons. Massive, multicolored mudstones from the upper part of individual cycles laterally and vertically grade into mixed-bioclastic or echinoderm facies and are locally strongly dolomitized or overgrown by Microcodium.

Interpretation: The formation of mudstones is generally explained by the deposition of very fine, suspended sediment particles under quiet-water conditions. The occurrence of mudstones at the base of individual cycles took place subsequent to the renewed flooding of the platform surface, when the carbonate factory was about to start up again. Hence, the facies probably formed under sediment-starved conditions when the production of biotically controlled sediment material was still low. In this position, the facies equates to the micritic facies of Morin et al. (1994), reflecting a quiet-water, deeper mid-shelf environment below the mean fair-weather wave base (FWWB).

At the top of the sequences, mudstones formed within protected, very shallow-marine to intertidal, lagoonal, or mudflat areas. The nearly complete absence of skeletal fragments may imply restricted marine, probably hypersalinare conditions.

\section{MFT 3: dolostones}

Description: This MFT comprises pure dolostones as well as limestones, whose predominant part of primary components and matrix is replaced by dolomite crystals. The very thick- to medium-bedded sediments commonly show light gray to whitish, yellowish or reddish colors and are marked by stylolites, a high moldic porosity and/or larger, irregularly shaped dissolution voids up to several centimeters in size.

Dolomites show a massive and predominantly equigranular texture, formed by closely packed, mainly subhedral to euhedral crystals ranging from silt- to fine-sand grain size (Fig. 6e). Primary sedimentary structures are generally obliterated. Occasionally, skeletal fragments (preferably echinoderms and/or brachiopod fragments) are still preserved while the former micritic matrix is completely replaced (porphyrotrophic fabric; Fig. 6f). Brownish translucent or opaque Fe-minerals occasionally form a thin crust around primary components.

The degree of dolomitization changes strongly within individual beds, resulting in the preservation of the primary sediment in smaller pockets, irregular areas or horizons of variable size or thickness. These areas feature peloidal and bioclastic wacke to packstones commonly containing fragments of echinoderms, brachiopods, corals and bryozoans, as well as foraminifers, peloids, ooids, Microcodium crystals or lithoclasts. Isolated, euhedral dolomite crystals of rhombic shape, embedded in the gray, yellowish or reddish micritic to microsparitic matrixes frequently occur.

Occurrence and associations: Dolomites and dolomitized limestone beds commonly occur in the upper part and at the very top of the individual cycles together with the Microcodium facies and/or sediments belonging to the caliche facies. In addition, they are associated with the peloidal, small-foraminifer, mixed bioclastic and reefal facies, which form the original sediments in less-dolomitized areas. 
Interpretation: The majority of the investigated dolostones are probably the matter of secondary dolomites, originating from the replacement of limestones, whose original fabrics are locally still present in horizons or irregular areas. Dolomitization probably took place during early diagenesis in shallow burial depths in connection with sealevel fluctuations and the emersion of the platform top. Different models, like the seepage-reflux model or the evaporation-drawdown model (Flügel 2004) propose dolomitization connected to the emersion of limestones, which seems to be most likely, considering the preferred lithostratigraphic position within the cycles, the association with other MFTs and the original fabric of the carbonate rocks.

\section{MFT 4: peloidal facies}

Description: This MFT is characterized by the abundant occurrence of peloids, which form one of the main component categories within massive, low-diverse, often densely packed and generally very well-sorted grainstones and packstones (Fig. 6g, h).

The spherical to irregularly shaped, gray to dark gray, 0.03-0.2 mm-sized peloids are generally well- to edgerounded and occasional show relicts of internal microstructures. They are always associated with encrusting smallforaminifers, fragments of Shamovella (formerly Tubiphytes) and echinoderms, which are abundant to common occurring constituents. In addition, fragments of bryozoans, gastropods, corals, ostracodes, calcareous algae and lithoclasts or ooids (radial or altered) occur in minor amounts. Microcodium is also commonly present as allochthonous single crystals are enriched within certain horizons or nests (Fig. 6h).

Occurrence and associations: The peloidal facies is common in the uppermost parts of cycles of all sections, showing gradual transitions into the ooidal, small-foraminifer or reefal facies. Overgrowth of autochthonous Microcodium aggregates or mats and the enrichment of allochthonous Microcodium crystals in pockets and horizons are common.

Interpretation: The majority of the peloids of this facies most likely originate from the disintegration and abrasion of encrusting organisms (foraminifers, Shamovella) and in minor amounts from the micritization of other bioclasts and ooids (algal and bahamite peloids). The generally wellsorted grain- and packstones were deposited above the FWWB within turbulent, shallow-submarine to intertidal areas of the inner platform. Here, peloids accumulated due to winnowing caused by weak tidal currents or wave action within semi-protected, lagoonal areas, probably in the vicinity of smaller reef knobs, on tidal flats or in more sheltered foreshore areas close to ooidal sand shoals. This interpretation generally matches the peloidal facies described by Hüneke et al. (2001), who assumed restricted lagoonal or tidal flat areas marked by moderate to low-energy conditions as the main depositional area of peloidal sediments.

\section{MFT 5: ooidal facies}

Description: This facies consists of (very) well-sorted, arenitic, ooidal grainstones and packstones, characterized by the abundant occurrence of radial-fibrous, micritic or altered ooids with grain sizes of up to $1 \mathrm{~mm}$ (Fig. 7a, b). Minor constituents besides the non-skeletal fragments are small foraminifers, peloids, lithoclasts and bioclasts of echinoderms, brachiopods and probably mollusks (recrystallized).

Radial-fibrous and micritic ooids show a gradual transition into each other, having both laminae composed of micrite and radially arranged crystals (Fig. 7a). The central nuclei of the grains mainly consist of smaller, recrystallized skeletal fragments, small-foraminifers or peloids. In contrast, the cortex of altered ooids entirely consists of sparry calcite, while the nuclei are predominantly formed of peloids probably due to micritization or recrystallization during early diagenesis. Altered ooids also often show a geopetal fabric caused by the gravitational collapse of the nuclei, which moved into a peripheral position at the bottom of the component during the dissolution of the cortex and prior to the subsequent precipitation of sparry calcite (Fig. 7b).

Occurrence and associations: This MFT solely has been found in sections L1 and MB1, occurring in thick- to intermediate-bedded limestones of certain cycles in the upper part of the entire sedimentary successions (Fig. 4) Here, the facies is associated mainly with the peloidal facies (rarely with the small-foraminifer facies) showing gradual vertical and lateral transitions into each other.

Interpretation: In accordance to Morin et al. (1994) and Hüneke et al. (2001), this facies reflects low-diverse, winnowed sands of barriers and shoals, which formed under higher energy conditions within the intertidal to shallowmarine platform interior. The formation of ooidal sands requires supersaturated and agitated water conditions, enabling the growth of concentric coatings, embracing the nuclei while the grains are in permanent movement and rotation. Considering the nuclei of the grains, the position within the cycles and the association with the other microfacies, ooid sand shoals probably formed along the foreshore or within specific lagoonal areas, where waves and/or tidal currents provided turbulent water conditions. Altered ooids probably originate from primary aragonitic, radial-fibrous ooids due to early diagenetic dissolution and recrystallization possess. Higher energy, barrier and shoal deposits (reflected within the oolitic, bioclastic, dasycladalean and oncoidal facies after Morin et al. 1994) are generally rare within the investigated strata of the Ny Friesland Platform. 

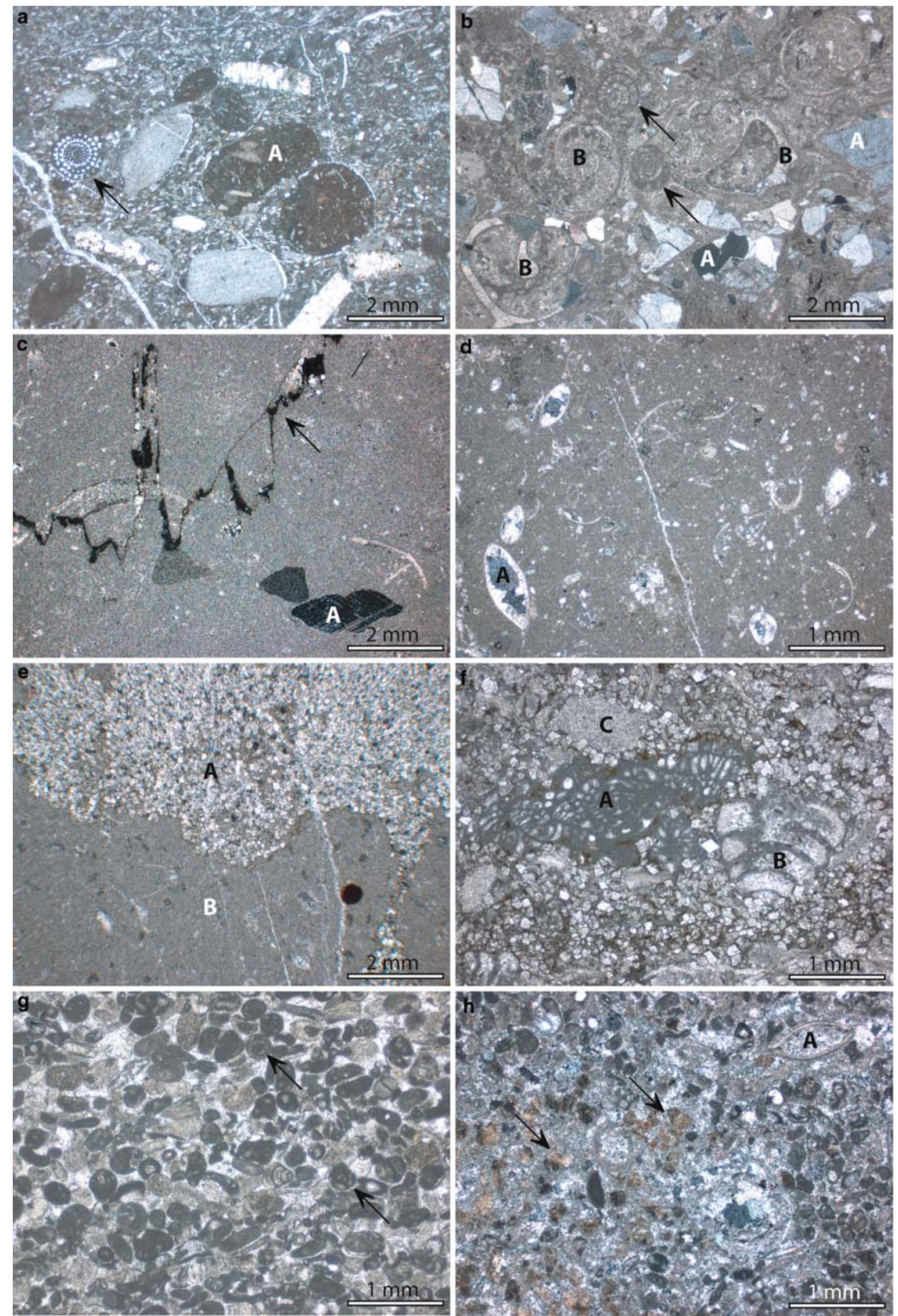
4 Fig. 6 Non-biotic microfacies: a Transgressive resediments (section L2, bed 7): This coarse-grained, poorly sorted litho to bioclastic rudstone contains a mixture of reworked material probably from the top of the underlying cycle (well-rounded, Fe-stained lithoclasts $(A)$ and sediment particles, which were deposited subsequent to the flooding of the platform surface (fusulinid foraminifer, arrow). b Transgressive resediments ("Section C1", bed 3): Calcareous gravel to sandstones from the basis of the platform strata at Carpethøgda. These deposits are marked by abundant, angular to edge-rounded quartz clasts (weathering products of the underlying basement rocks, $A$ ), occasional occurring, ruditic gastropod shells $(B)$ and staffellid foraminifers (arrows), embedded in a multicolored, micritic to microsparitic matrix. c Mudstone facies ("Section C1", bed 32): This mudstone generally consists of a heterogeneous, gray-reddish microsparitic matrix. Scattered skeletal fragments mainly comprise echinoderm $(A)$ or brachiopod remains. Pressure solution is displayed by occasional occurring stylolites (arrow). d Mudstone facies ("Section D1", bed 32): In places, completely preserved ostracodes $(A)$, filled with blocky sparite occur. Note the enrichment of filaments and silt-sized quartz grains within the micritic, partly Fe-stained matrix. e Dolostone/mudstone facies ("Section D1", bed 32): A fine crystalline dolomite $(A)$ with an equigranular texture, formed by closely packed, subhedral to euhedral crystals replaces a micritic limestone (mudstone facies, $B$ ). The unimodal size distribution of the crystals suggests a single-phase formation of the dolomite. f Dolostone facies ("Section D1", bed 20b): A dolomite, characterized by a distinct red, Fe-stained matrix and euhedral, rhomb-shaped dolomite crystals, shows a partially replacement of the original sediment. The latter is merely preserved by foraminifers (A Beedeina sp.; B Palaeotextulariid foraminifera) and strongly micritized skeletal fragments (C). g Peloidal facies ("Section C1", bed 41): Peloids and echinoderm fragments form the main component constituents within this very well sorted, closely packed, peloidal grainstone. Dark colors and internal structures (arrows) of the peloids imply that the grains mainly formed from the disintegration and reworking of encrusting organisms (smallforaminifers, Shamovella). h Peloidal facies ("Section C1", bed 4): The occurrence of light-brownish, allochthonous Microcodium crystals (arrows) enriched within this well-sorted, poorly washed, peloidal grainstone points to the isochronous reworking of palaeosols. Minor constituents are represented by ostracode shells $(A)$

\section{MFT 6: Microcodium facies}

Description: This MFT is characterized by the massive occurrence of light brownish to yellowish, elongated, sparry calcite crystals (Fig. 7c, d), which have equant to bladed, subhedral shapes with average lengths of $0.3-$ $0.7 \mathrm{~mm}$ (max.: $1 \mathrm{~mm}$ ) and widths of $0.06-0.12 \mathrm{~mm}$. The crystals either occur as isolated grains or are connected along their longitudinal axis in order to form composite aggregates and larger, multilayered masses. Within radialstructured, petal-like aggregates, occasionally a central cavity filled with dark micritic material is present.

The MFT comprises both autochthonous and allochthonous Microcodium deposits. Autochthonous Microcodium commonly comprises isolated, smaller aggregates to larger masses consisting of stacked crystal layers completely replacing (overgrowth, displacive precipitation) the primary host sediment (Fig. 7c). Allochthonous Microcodium is composed of single, edge-rounded crystals or smaller aggregates, which are enriched in restricted, irregularly shaped areas within the host sediment (Fig. 6h). Within these areas, the Microcodium fragments often form a crystal/grain-supported packstone fabric, together with other scattered non-skeletal (peloids, quartz grains) and skeletal components (mainly echinoderm fragments). Microcodium often includes or is bounded by stylolites, on which $\mathrm{Fe}$ minerals or insoluble residue is concentrated.

Occurrence and associations: The Microcodium facies commonly occurs within sub-parallel to perpendicular to the bedding surfaces orientated irregularly shaped pockets or veins, or form thin, laterally discontinuous horizons or layers within the marine host sediments at the very cycle tops of all sections. The MFT is associated with the caliche, small-foraminifer, reefal and peloidal facies, where it locally occurs as autochthonous overgrowths or forms enrichments of allochthonous Microcodium crystals.

Interpretation: Microcodium is especially common in Late Paleozoic, marine carbonates and has been frequently described in literature (see Kabanov et al. 2008). As it commonly occurs on subaerial emersion surfaces reaching down to a few meters into the underlying marine strata, its biogenic subsurface, non-marine nature is widely accepted. Although the specific formation is still under discussion (calcified mycorrhizae of root cells after Klappa 1978; saprotrophic fungi and actinobacteria after Kabanov et al. 2008), the occurrence of this microfacies clearly signals the cessation of marine conditions connected with a prolonged subaerial exposure of the marine sediments in a terrestrial setting.

Thus, the occurrence of autochthonous Microcodium at the top of individual cycles reflect in situ Microcodium growth in areas of the emerged platform surface, while allochthonous disintegration products were coevally redeposited within adjacent, still submerged areas.

\section{MFT 7: caliche facies}

Description: This MFT comprises a variety of microfabrics, which are all marked by distinct reddish colors due to $\mathrm{Fe}$-staining and to a different extend by features originating from alteration, recrystallization, and dissolution processes (Fig. 7c, e, f). Hence, the varied skeletal and non-biotic components are often micritized, marginally dissolved or coated with thin, red Fe-laminae. The micritic matrix is commonly strongly Fe-stained and often recrystallized to microsparite. Solution seams, stylolites, cracks filled with cements or internal sediments, opaque Fe-minerals, nodular or brecciated fabrics are common.

A conspicuous fabric constitute silty mudstones, which form lateral restricted, commonly only a few centimeters thick beds or lenses with sharp boundaries. The sediments partially have a high porosity due to the common occurrence of small dissolution voids (moldic porosity) and are 

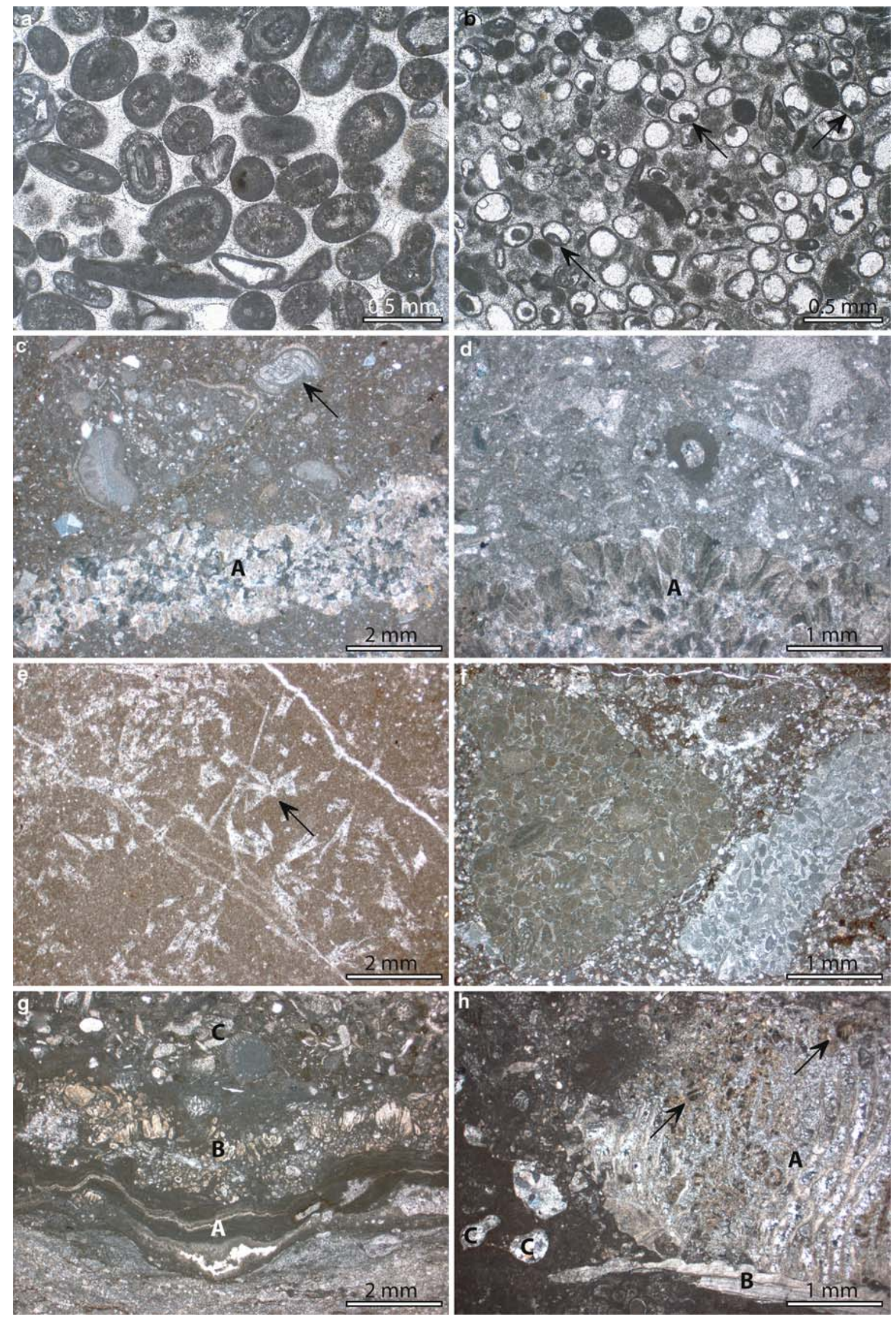
4 Fig. 7 Non-biotic facies: a Ooidal facies ("Section L1", bed 55): Well-sorted ooids with micritic to radial-structured cortexes form a component supported fabric within this rather loosely packed, wellwashed, ooidal grainstone. The nuclei mainly consist of recrystallized bioclasts or peloids. b Ooidal facies ("Section L1", bed 54): This poorly washed ooidal grain to packstone shows altered ooids with a cortex of sparry calcite as the main component constituent. The grains often form a geopetal fabric (arrows) due to the dissolution of the original aragonitic cortex and subsequent gravitational collapse of the majority of the nuclei to the bottom of the grain (dissolution-fill structure). $\mathbf{c} \mathrm{Mi}$ crocodium/caliche facies ("Section C1", bed 4): This facies association shows a poorly sorted, Fe-stained caliche (peloidal, litho to bioclastic wacke to packstone with a poorly preserved staffellid foraminifer, $a r$ row), which is overgrown by a sub-horizontal vein of autochthonous Microcodium (A). d Microcodium facies (Section D1, bed 30): Autochthonous Microcodium $(A)$ replaces a bioclastic wacke to packstone (mixed-bioclastic facies). Note the sub-parallel orientation of the bladed crystals along the growth front. e Caliche facies ("Section C1", bed 37): This fine-grained, distinct red-colored mudstone, forming a capping horizon of a parasequence, shows abundant gypsum or salt pseudomorphs (arrow), reflecting subaerial exposure and evaporation under arid conditions. f Caliche facies ("Section C1", bed 33): This distinct red colored, lithoclastic rudstone is marked by the occurrence of ruditic, edge-rounded intraclasts showing an internal, peloidal packstone or grainstone fabric (MFT 4 peloidal facies). The reworked components are embedded by a strongly altered, Fe-stained, fine-grained packstone with a microsparitic matrix. g Caliche facies ("Section C1", beds 6/7): This facies reflects a palaeosol, which is marked by an undulating, laminar horizon $(A)$, a Microcodium layer $(B)$ and a poorly sorted bioclastic packstone $(C)$, comprising various bioclasts embedded in a strongly Fe-stained, micritic matrix. h Caliche facies: (Section D1, bed 20): This poorly sorted, peloidal, litho to bioclastic rudstone shows a chaetitid $(A)$, which used a shell fragment $(B)$ as growth substrate. The organism is partly overgrown by Microcodium (arrows). Tubular structures $(C)$ lined with Fe-stained micrite and filled with blocky sparite may represent root traces

characterized by a massive, Fe-stained, microsparitic matrix, which show abundant silt-sized Microcodium crystals and occasional detrital quartz grains. Opaque, irregularly shaped (dendroid) mineral accumulations are locally common, insoluble residue is concentrated on the irregular surfaces of occasional occurring stylolites; salt- or gypsumpseudomorphs occur rarely (Fig. 7e). Scattered components, embedded in the matrix consist of peloids, larger, well-rounded lithoclasts (with internal mudstone to peloidal packstone fabrics) and mainly arenitic echinoderm or brachiopod fragments. Locally, these mudstones are fragmented or brecciated, thus forming lithoclastic rudstones consisting of large, angular to edge-rounded mud chips (autoclasts) with an internal mudstone fabric.

Other types of lithoclastic rudstones (intramicrudites) are marked by the abundant occurrence of edge-rounded intraclasts showing various internal fabrics (peloidal, mudstone, mixed-bioclastic MFTs), which are embedded in a distinct red, partly silty, microsparitic matrix (Fig. 7f).

The most common microfabrics of the caliche facies are massive, medium-bedded, peloidal, litho to bioclastic pack to rudstones and minor wacke to floatstones, which show a strongly changing, high-diverse composition of the biotic and/or non-biotic components (Fig. 7g, h). These (very) poorly sorted sediments are generally marked by a distinct red, partly clotted, micritic to microsparitic matrix, in which fragments and biogens of tabulate and rugose corals, echinoderms, brachiopods, gastropods, calcareous algae, bryozoans, different foraminifers, ostracodes, Microcodium crystals and aggregates, lithoclasts and peloids are embedded in, preferably forming a component-supported fabric. The components, which show no orientation and an irregularly distribution often have sutured contacts and occasionally are silicified (skeletal fragments). A primary indistinct horizontal lamination by the parallel orientation of elongated components is often destroyed by bioturbation (burrowing) or by irregularly shaped, perpendicular to subhorizontal to the bedding planes oriented root traces, which are filled by sparite, Microcodium or internal sediment. In places, a nodular fabric, marked by the formation of up to a few centimeter large, edge-rounded nodules, which are often outlined by dark seams, can be observed. Additionally, opaque mineral separations and insoluble mineral concentrations on occasionally occurring, lowrelief stylolites are commonly present.

Occurrence and associations: The facies exclusively occur at the very top of individual cycles, often forming conspicuous red, lateral restricted, medium- to thin-bedded, irregularly capping horizons. The sediments show both gradual and sharp, irregularly transitions into dolostones or limestones containing the Microcodium, peloidal, mixedbioclastic, small-foraminifer or reefal facies.

Interpretation: The varied peloidal, litho to bioclastic pack to rudstones (wacke to floatstones) represent the uppermost, emerged marine platform strata, which were superimposed and subjected to meteoric alteration, dolomitization and pedogenesis in a sabkha-like environment. Inplace fragmentation and brecciation results form the desiccation and shrinkage of the sediments under arid to semiarid climatic conditions. Subsequent transport is reflected by the occurrence of lithoclastic rudstones. The development of distinct red colors is due to the oxidizing of iron minerals and other mineral separations. The occurrence of root traces, carbonate nodules and Microcodium reflects the development of immature palaeosols during subaerial exposure. Early to late diagenetic cementation and/or pressure-dissolution processes are reflected in the formation of stylolites and the marginal dissolution of components (Flügel 2004). Distinct red, partly fragmented mudstones are interpreted as the deposits of laterally restricted caliche hardpans or crusts formed in smaller depressions or rock pools (Kamenitzas).

The occurrence of this microfacies clearly indicate a hiatus of the marine sedimentary record due to the emergence of the 

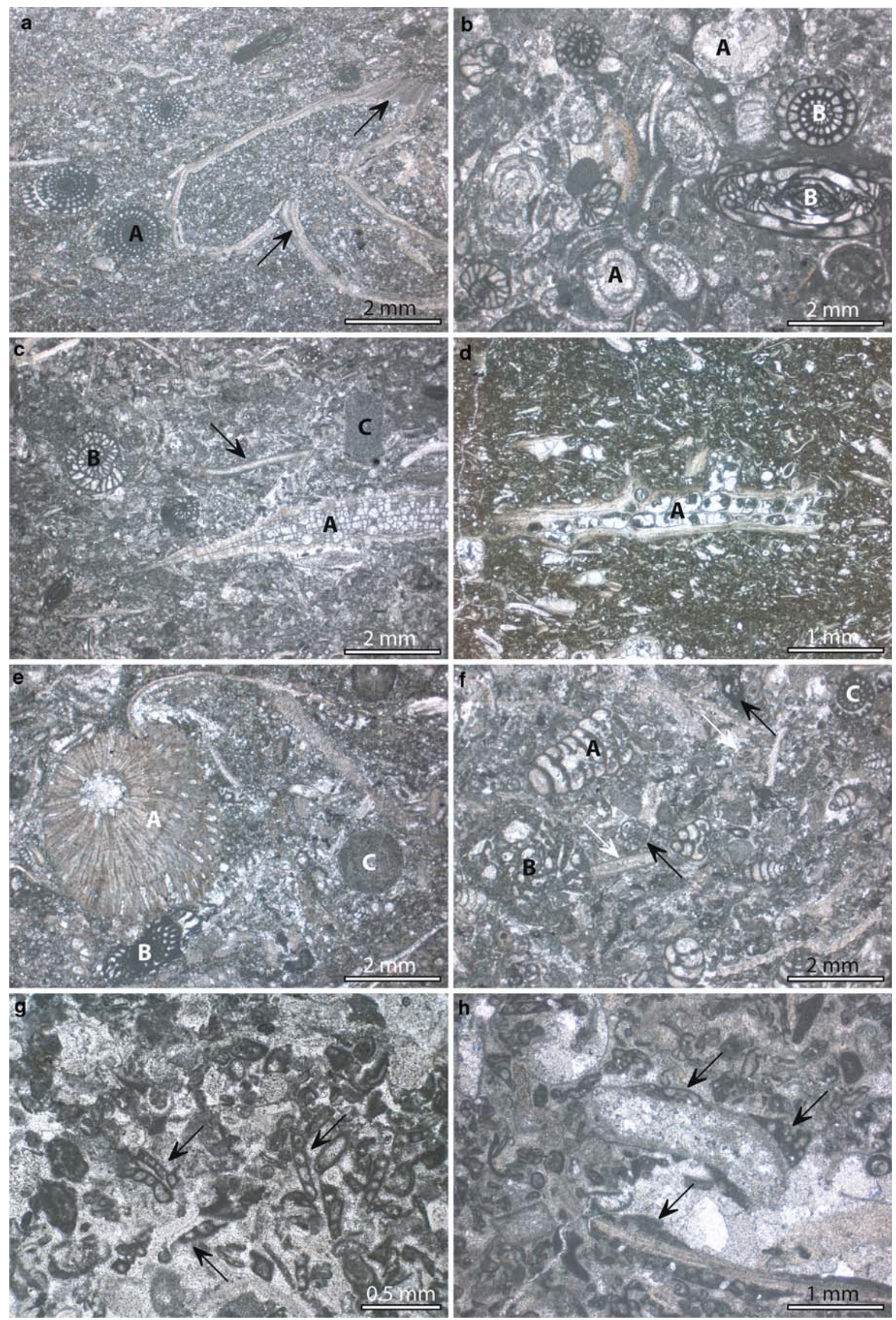
4 Fig. 8 Bioclastic facies: a Fusulinid-foraminifer facies ("Section C1", sheet 17): This bioclastic wackestone is characterized by the common occurrence of fusulinid foraminifers $(A)$ and ruditic brachiopod shells (arrows), embedded in a silty to muddy matrix consisting of undetermined, very fine grained shell fragments and micrite. b Fusulinid-foraminifer facies ("Section C1", sheet 34): The association of staffellid (A) and fusulinellid (B Fusulinella sp.) foraminifers (here forming a component-supported fabric) is characteristic for the shallowest marine facies, often connected to subaerial exposure surfaces. Due to the dissolution of the primary aragonitic skeletal substance, staffellid foraminifers are often preserved as molds filled with blocky sparite. c Brachiopod/bryozoan facies (Section D1, bed 21): This poorly sorted, coarse-grained, bioclastic packstone shows a larger fragment of a fistuliporid bryozoan $(A)$, which is characterized by a bubble-like meshwork (cystopores) and a longitudinal section of a brachiopod spine (arrow). Together with fusulinid foraminifers $(B)$ and echinoderm fragments $(C)$ the skeletal fragments form the main component constituents of this facies type. d Brachiopod/bryozoan facies (section L2, bed 4): Fragments of fenestrate bryozoans $(A)$ form the most prominent component category of this facies. The larger bioclasts often have a lattice-like appearance; smaller disintegration products form a considerable part of the heterogeneous, silty matrix. e Mixed-bioclastic facies ("Section C1", bed 20): Moderate to poorly sorted bioclastic wacke to packstones (float to rudstones) constitute a highly diverse biotic association consisting of, e.g., bryozoans $(A)$, fusulinid foraminifers $(B)$ and echinoderms $(C)$. f Mixed-bioclastic facies ("Section C1", bed 24): This bioclastic packstone shows a highly diverse biotic association consisting of encrusting (black arrows) and benthic small-foraminifers (A palaeotextulariid; $B$ bradyinid), $C$ fusulinids and fenestrate bryozoan fragments (white arrows). g Small-foraminifer facies ("Section L1", bed 55): The component composition of this well-sorted, wellwashed grainstone is characterized by the common to frequent occurrence of small, encrusting foraminifers (Calcivertella sp., arrows) and peloids, which probably originate from the disintegration and reworking of the encrusting organisms. $\mathbf{h}$ Small-foraminifer facies ("Section C1", bed 25): Larger, completely recrystallized skeletal fragments of this poorly washed and moderate-sorted grainstone were used as a hard substrate for encrusting small-foraminifers (arrows)

carbonate platform surface and thus reflects exposure surfaces, which mark the upper boundary to the overlying cycle.

\section{Bioclastic facies}

Bioclastic grain, pack and wackestones (rud and floatstones) are the most common microfacies types of the limestones. The allochthonous sediments show a highly diverse and strongly varying composition of the skeletal grains (Tables 1,2). Throughout the single cycles, the composition of the bioclastic facies gradually changes and shows the predominance of certain biotic assemblages in combination with characteristic fabrics.

\section{MFT 8: fusulinid-foraminifer facies}

Description: This MFT is formed by moderately sorted, bioclastic wackestones and minor packstones, which are marked by the significant proportions of fusulinid foraminifers (e.g., Schubertella, Fusiella, Ozawainella, Neostaffella, Quasifusulinoides, Wedekindellina, Pseudofusulinella,
Fusulinella, Beedeina, Protriticites, and staffellids). Throughout the sedimentary succession of the single cycles, two main assemblages are distinguished. Beedeina, Neostaffella and Wedekindellina often are associated within bioclastic wackestones, which show also higher amounts of fragments from bryozoans, brachiopods, or echinoderms (Fig. 8a). The heterogeneous, partly silty matrix of the sediments predominantly consists of micrite with enrichments of very fine, unidentified biodetritus (filaments). A primary, indistinct horizontal lamination formed by the parallel orientation of elongated shell fragments and the occurrence of pure micritic layers is often obliterated due to bioturbation. In addition, Fusulinella/Protriticites and staffellid foraminifers are also enriched together within sediments of the mixed-bioclastic, caliche, transgressive resediments and reefal facies (Fig. 8b). Sediments containing this fusulinid association are generally higher diverse and comprise a wide range of skeletal fragments of bryozoans, brachiopods, echinoderms, arthropods, small foraminifers (Bradyina, Palaeotextulariidae), corals (tabulate and rugose) and lithoclasts or peloids in varying amounts.

Occurrence and associations: The fusulinid-foraminifer facies commonly occurs within medium-bedded limestones of the lower part of the cycles, showing gradual lateral and vertical transitions into the brachiopod/bryozoan and mixed-bioclastic facies.

Interpretation: Fusulinid foraminifera inhabited a wide spectrum of living environments from nearshore, clastic influenced to deeper subtidal conditions. From the associated facies types, it can be supposed that the majority of species preferred open marine, stenohaline conditions. Fusulinids lived epifaunal on the substrate, or on marine algae (e.g., phylloid algae). It is generally assumed that fusulinid foraminifera harbored symbiotic algae or cyanobacteria (Ross 1972; Vachard et al. 2004; Leppig et al. 2005). Depending on the type of symbiotic algae, a water depth distribution from a few meters down to $70 \mathrm{~m}$ can be deduced from modern analogues (Stevens 1969; Leutenegger 1984).

Within the investigated strata Beedeina, Neostaffella, and Wedekindellina preferably occur in the lower part of single cycles representing a deeper, subtidal facies of the mid-platform, which corresponds to the fusulinacean facies of Morin et al. (1994). In contrast, Fusulinella/Protriticites occur also together with MFTs generally reflecting shallower areas of the platform interior. Similar conclusions on the facies distribution of fusulinids have been drawn by Baranova and Kabanov (2003) from the Moscow Basin.

\section{MFT 9: brachiopod/bryozoan facies}

Description: The component composition of these poorly to moderately sorted wackestones (floatstones) and minor 
packstones is characterized by the predominance of arenitic to ruditic fragments and complete biogens of impunctate, pseudopunctate and/or punctate brachiopods (shells and spines) and of fenestellid, fistuliporid and ramose bryozoans (Fig. 8c, d). Fusulinid foraminifers, fragments of echinoderms and peloids constitute common, additional component types, while fragments of tabulate and rugose corals, mollusks and small foraminifers form only minor component constituents. The bioclasts are embedded in mainly gray but also brownish micritic to microsparitic matrixes, which contain a considerable part of very fine, unidentified biodetritus (filaments, probably originating from the decay of brachiopods and bryozoans). Occasionally, an indistinct wavy-horizontal bedding/lamination is formed by the parallel orientation of elongated (shell) fragments and their enrichment in thin-bedded horizons. Bioturbation is common, often obliterating the primary structures.

Occurrence and associations: This microfacies mainly occurs in the lower part of individual cycles and preferably in the lower part of the entire platform succession. The MFT is associated with the fusulinid-foraminifer and mixed-bioclastic microfacies, forming medium- to thinbedded limestone beds.

Interpretation: These sediments reflect mud flats within the deeper subtidal below mean FWWB, characterized by low-energy, open-marine conditions. The latter led to the deposition of suspended lime mud and fine bioclastic particles (filaments) embedding arenitic to ruditic bioclasts and biogens. A primary horizontal lamination is often obliterated by bioturbation, indicating oxygenated sea bottom conditions, which allowed the predominance of a fauna mainly consisting of brachiopods, bryozoans and echinoderms with sediment feeders burrowing the ground. Corresponding to the bryozoan facies of Morin et al. (1994), this MFT reflects a low-relief, open sea shelf (mid-platform) grading into the generally shallower and more restricted areas of the platform interior.

\section{MFT 10: mixed-bioclastic facies}

Description: This MFT consists of massive, moderate to poorly sorted, mainly arenitic, bioclastic wacke to packstones (minor float to rudstones), which show strongly varying component compositions of highly diverse biotic associations without the predominance of any specific component type (Fig. 8e, f). The components mainly consist of fragments of calcareous algae, rugose and tabulate corals, brachiopods, bryozoans, echinoderms, mollusks and various small and fusulinid foraminifers. Peloids and intraclasts occur as minor constituents. The components, which reach up to a few centimeters in size (preferably coral debris), predominantly show no preferred orientation or distribution and are embedded in heterogeneous, reddish or grayish micritic to microsparitic matrixes often mixed with very fine, unidentified biodetritus (filaments, probably originating from the decay of ostracodes, juvenile brachiopods, algae, tabulate corals or chaetetids). Occasionally, an indistinct wavy-horizontal bedding is shown due to the parallel orientation of elongated components.

Occurrence and associations: This facies occurs throughout the entire platform succession in all sections, without a preferred position within the single cycles. It grades into the fusulinid-foraminifer facies or brachiopod/ bryozoan facies but also is associated with the reefal and small-foraminifer facies further up in strata of the single cycles.

Interpretation: The MFT represents an accumulative group of fabrics, which could not clearly assigned into one of the other MFTs and thus is not indicative of any specific depositional environment of the carbonate platform. In the lower parts of the cycles, it probably formed under low to moderate energy conditions below or around the mean FWWB on submarine, muddy flats of the mid-platform, where waves and currents were insufficient to remove the fine-grained matrix. Further up in strata, it represents sediments deposited on open marine, shallow-marine flats of the platform interior, probably in the vicinities of smaller reefal structures, which yield the diverse bioclastic material.

\section{MFT 11: small-foraminifer facies}

Description: This MFT mainly comprises massive, well (to moderate) sorted, fine arenitic, often densely packed, bio to biopeloidal grainstones and packstones (similar to the small-foraminiferal facies of Hüneke et al. 2001 and foraminiferal facies of Morin at al. 1994). The sediments are characterized by the abundant occurrence of smaller benthic foraminifers comprising palaeotextulariids (Climacammina, Cribrogenerina, Deckerella, Palaeotextularia), tetrataxids (Tetrataxis) and bradyinids, associated with sessile encrusting foraminifera (Apterinella, Calcitornella, Tuberitina) and the microproblematicum Shamovella (Fig. 8g, h). Fragments of echinoderms and peloids, probably mainly originating from the abrasion of encrusting, fine-agglutinated foraminifers also form significant proportions. Fusulinids of the genus Staffella occasionally occur within this MFT. Single Microcodium crystals are locally enriched within horizons. Other non-skeletal components are represented by rare ooids and lithoclasts. Skeletal fragments of rugose and tabulate corals, brachiopods, molluscs, and bryozoans are occasionally present and partly act as substrate for the encrusting foraminifers.

Occurrence and associations: This facies is quite prominent within the platform strata and commonly forms 
medium-bedded horizons or beds preferably in the upper part and top of the stacked cycles. Lateral and vertical transitions into the reefal facies, peloidal facies, and overgrowth by Microcodium are common.

Interpretation: This facies generally was deposited above the mean FWWB within the shallow-subtidal to intertidal areas of the platform interior. It forms fine arenitic, low-diverse sand shoals mainly consisting of smaller foraminifers, peloids (MFT 4) and echinoderm fragments, which were washed by moderate currents generated by tides or waves within very shallow, foreshore areas associated with small reefal (coral) biostromes. Autochthonous Microcodium overgrowth reflects the subaerial exposure of these areas in periods during low sea level, allochthonous Microcodium crystals may reflect nearby areas, which were contemporaneously subaerially emerged.

\section{MFT 12: echinoderm facies}

Description: This MFT comprises moderately sorted, arenitic wackestones (rare floatstones) and minor packstones, which are characterized by a low-diverse component composition mainly consisting of medium to coarse sand-sized fragments of crinoids or echinoids (Fig. 9a, b).

The components are generally marked by a typical syntaxial overgrowth or honeycomb structure and sometimes show dissolved margins. Together with occasional occurring brachiopod fragments and rare foraminifers, bryozoans, peloids and corals, the bioclasts are embedded in gray, brownish, yellowish or reddish colored, Fe-stained microsparitic matrixes. Indistinct horizontal bedding due to a component accumulation in layers and the parallel orientation of elongated fragments is occasionally visible. The sediments partially show the occurrence of opaque mineral separations and euhedral dolomite crystals in varying amounts.

Occurrence and associations: Echinoderm fragments are present in varying amounts within all bioclastic and reefal microfacies types and form a prominent constituent within the peloidal, small-foraminifer, mixed-bioclastic and brachiopod/bryozoan facies. In smaller amounts, they also occur in the transgressive resediments, dolostones and sediments of the ooidal and caliche facies. However, lowdiverse echinoderm-rich wackestones predominantly occur within gray to yellowish or reddish colored, thick- to medium-bedded, massive limestones from the upper part of the cycles, where they are associated with massive mudstones and are partly replaced by dolostones.

Interpretation: Echinoderms provide a prominent component category on the platform surface. Their fragments are present within most of the facies types, reflecting a widespread depositional area ranging from deeper submarine muddy flats of the mid shelf to near-shore, intertidal areas of the platform interior. Considering the fabric and top-position within individual cycles, echinoderm wackestones probably reflect protected lagoonal or tidal flat, quiet-water areas in the intertidal zone marked by restricted marine conditions. The occurrence of low-diversity echinoderm associations points to a stressed environment probably due to changing salinity, oxygenation, and temperature.

\section{Reefal facies}

The reefal facies of the investigated strata comprises a variety of smaller in situ build-ups and their parautochthonous decomposition products. Included are locally occurring populations of solitary rugose corals (coral meadows) and reefal structures with colonial rugose and tabulate corals, various calcareous algae and the problematicum Palaeoaplysina as main sediment baffler.

\section{MFT 13: coral reefal facies}

Description: This MFT includes local "coral meadows" of some meters lateral extension, formed by a dense population of horn-shaped, solitary rugose corals with maximum growth lengths of up to $20 \mathrm{~cm}$ (Fig. 5h). The parautochthonous sediments from these areas are described as coral floatstones, marked by either complete corallites or larger fragments embedded in a micritic matrix, together with other bioclasts and biogens (mainly from bryozoans) in varying amounts.

More common are biostromes formed by in situ preserved, colonial tabulate and rugose specimens. Flat-topped colonies of tabulate corals show maximum lateral extensions of up to $2 \mathrm{~m}$ and heights of up to $25 \mathrm{~cm}$. They have robust, branching growth forms and consist of separated, circular corallites with a diameter of up to $2 \mathrm{~cm}$ (Fig. 9c, d). Rugose corals with a Syringopora-like appearance form generally smaller (some centimeters to a few decimeters lateral extension), delicate, branched colonies, consisting of slender, oval to circular, separated corallites (max. $5 \mathrm{~mm}$ diameter), which are joined by cross-tubes (Figs. 9e, f). The parautochthonous sediments deposited in the interspaces and vicinity of these coral bafflestones consist of bioclastic packstones to grainstones (rudstones), which are generally poorly sorted due to the presence of coarser coral debris. They comprise a varied component composition with highly diverse biotic assemblages mainly consisting of fragments of other sessile organisms like various smaller foraminifers (e.g., Calcitornella, Tuberitina), bryozoans, calcareous algae and Shamovella, but also abundant to common echinoderm fragments, peloids and Microcodium crystals.

Up to ca. $20 \mathrm{~cm}$ high, domal to robust-branching specimens of Chaetetes, recently assigned to coralline sponges (Flügel 2004) are also included within this facies. 

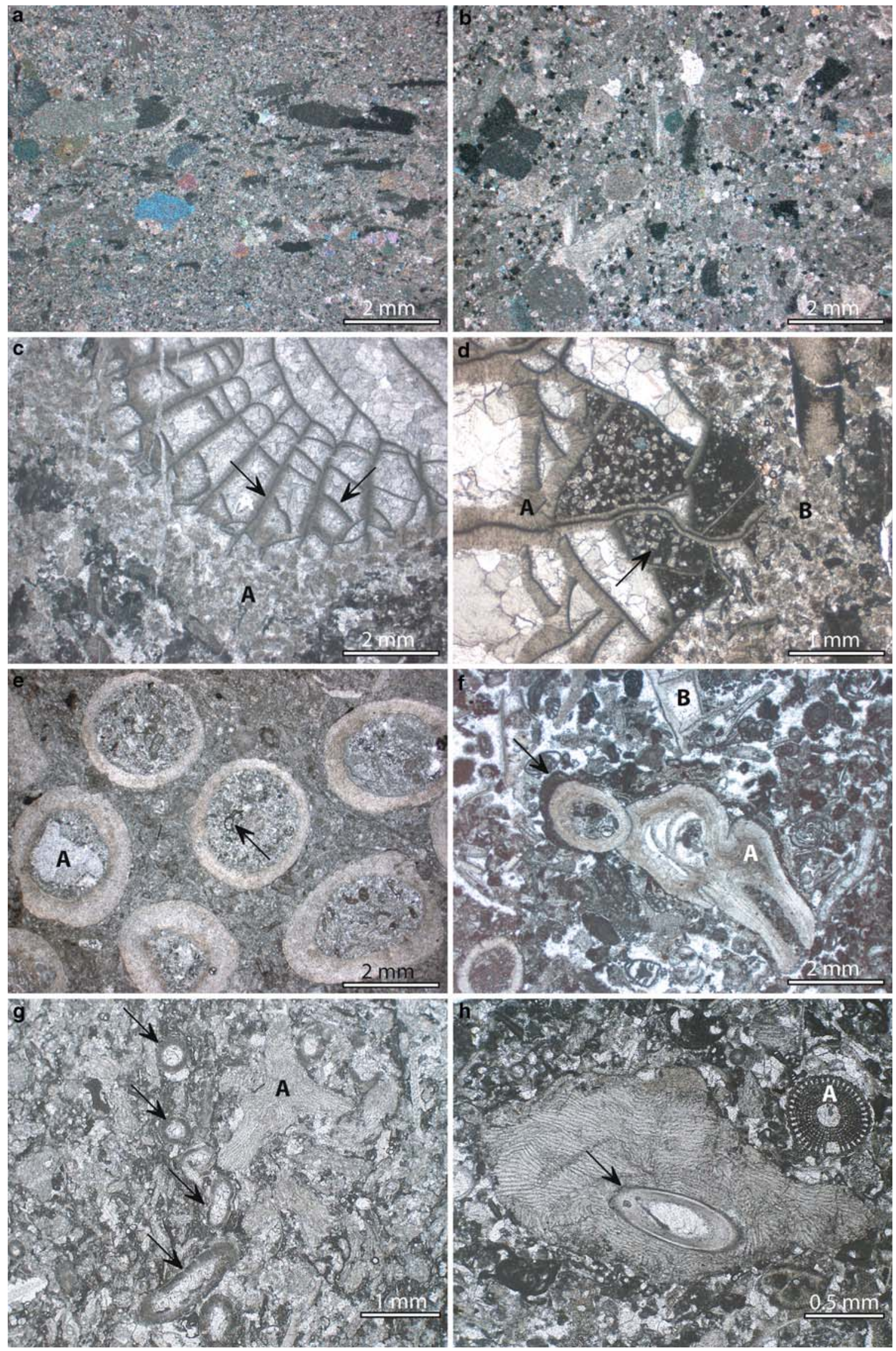
4 Fig. 9 Bioclastic and reefal facies: a Echinoderm facies ("Section C1", bed 22): The low-diverse, bioclastic wakestones often show primary horizontal bedding due to the accumulation of parallel oriented, elongated echinoderm fragments, which are embedded in a often strongly recrystallized, microsparitic matrix. b Echinoderm facies ("Section C1", bed 38): The bioclastic wackestones of this facies often show a gradual transition into the dolostone facies due to the replacement of both the microsparitic matrix and the echinoderm fragments by fine-grained, euhedral, rhombic dolomite crystals. c Coral reefal facies ("Section C1", bed 41): Cross section through a single corallite of a colonial rugose coral, showing early marine, fibrous calcite cements on radial-oriented septae and dissepiments (arrows), and a subsequent cement generation of blocky sparite filling the remaining voids. The coral is embedded in a grainstone with abundant small-foraminifers and marginally overgrown by autochthonous Microcodium (A). d Coral reefal facies (section L2, bed 25): The walls of this rugose coral $(A)$ are characterized by darker central stripes, which are surrounded by perpendicular oriented, light-brownish fibrous calcite cements. Most of the internal cavities of the corallite are cemented by blocky spar; chambers filled with dark micrite show the growth of euhedral dolomite crystals (arrow). The original fabric of this bafflestone is partly replaced by Microcodium (B). e Coral reefal facies (Section D1, bed 38): This bafflestone is formed by light brownish, thick-walled, isolated corallites of a colonial tabulate coral (type Syringopora). The transverse section shows a fibrous wall structure of the round- to ovalshaped corallites, which are partly cemented by blocky sparite $(A)$ or filled by internal sediment (with an encrusting small-foraminifer, $a r$ row). f Coral reefal facies ("Section L1", bed 5): Thick-walled, branching corallites of tabulate corals $(A)$ are composed of a light brownish, fibrous, primary calcitic, skeletal substance. The coral is partly filled and surrounded by a grainstone corresponding to the small-foraminifer facies. Note the marginal growth of encrusting organisms (arrow) and fragments of rugose corals $(B)$ in the surrounding sediment. $\mathbf{g}$ Algal mound facies ("Section L1", bed 1): This coarse-grained, densely packed, bioclastic packstone shows an association of irregularly shaped red algae fragments $(A)$ and round to oval beresellid green algae (arrows) fragments. h Algal mound facies ("Section L1", bed 4): Fragments of coralline red algae (Ungdarella, Epistacheoides) are characterized by an internal, elongate, cellular or tubular structure. The algal fragment is embedded in deposits corresponding to the small-foraminifer facies ( $A$, echinoderm fragment). Note the boring of an annelid worm, which is lined by a two-layered wall showing a lighter, concentrically laminated inner layer and darker, outer part

Occurrence and associations: Within the single cycles, the different coral reef structures show a specific distribution. Coral meadows formed by the enrichment of solitary rugose corals are relatively rare and predominantly appear in the lower part of individual sequences in the lower part of the entire succession.

In contrast, single chaetetids and smaller biostromes formed by colonial rugose and tabulate corals commonly occur throughout the entire platform strata, but predominantly within the middle and upper parts of individual cycles. The small, isolated biostromes or coral knobs very rarely exceed the thickness of the medium- to thick-bedded beds, they are embedded in. The surrounding sediments often correspond to the mixed-bioclastic, small-foraminifer or peloidal facies. Coral bafflestones are also associated with the Microcodium facies either by their partial replacement due to autochthonous Microcodium, or by the accumulation of allochthonous Microcodium crystals within the embedding sediment (Fig. 9c, d).

Interpretation: Chaetetids, tabulate, and rugose corals formed prominent elements of the platform surface and were present in a wide range of depositional environments. Coral meadows marked by a dense population of solitary rugose corals preferably formed under open-marine, quieter-water conditions on muddy sea flats of the mid-platform, generally below the mean FWWB within the deeper subtidal.

Chaetetids, colonial rugose and tabulate specimens in contrary, were more common within the shallow submarine to intertidal areas of the platform interior, as they generally occur more often higher in the strata of the single sequences. The organisms formed the main constituents of isolated, rather tabular, low-relief coral knobs (Scholle et al. 1983) associated with calcareous algae and encrusting organisms stabilizing the intergrowth. The flat-topped biostromes grew under variable energy conditions generally above the mean FWWB on extended, open-marine reef flats and probably within more restricted, lagoonal areas.

\section{MFT 14: algal mound facies}

Description: This MFT comprises the autochthonous structures and parautochthonous sediments, which emanate from the local presence of calcareous algae, such as coralline red algae, dasycladalean green algae and phylloid algae. The algal mound facies include low-diverse, densely packed, bioclastic packstones (rudstones) characterized by enrichments of irregularly formed red algae fragments (Ungdarella, Epistacheoides; Fig. 9g, h), bafflestones nearly exclusively consisting of elongated, cylindrical thalli of dasycladalean beresellid green algae (Beresella, Dvinella; Fig. 10a, b); and boundstones formed by poorly preserved phylloid algae (Fig. 10c, d). While associations of red algae and beresellid algae have been noticed, phylloid algae were solely documented within monospecific boundstones, surrounded by a partly clotted, micritic matrix comprising rare foraminifers and brachiopod fragments. Due to the primary aragonitic mineralogy and resulting very poor preservation, the algal fragments were rather recognized by their platy, irregular shape than by internal structures.

Occurrence and associations: Autochthonous algal structures or the rock-forming accumulation of their fragments have been noticed only rarely within the investigated platform strata. Smaller enrichments of red algae have been noticed from the lower part of individual cycles in "Section L1" and "Section MB1", where they are associated with solitary rugose corals and are grown up on coarse-grained deposits belonging to the transgressive resediment facies. Accumulations of the beresellid green algae occur solely in 

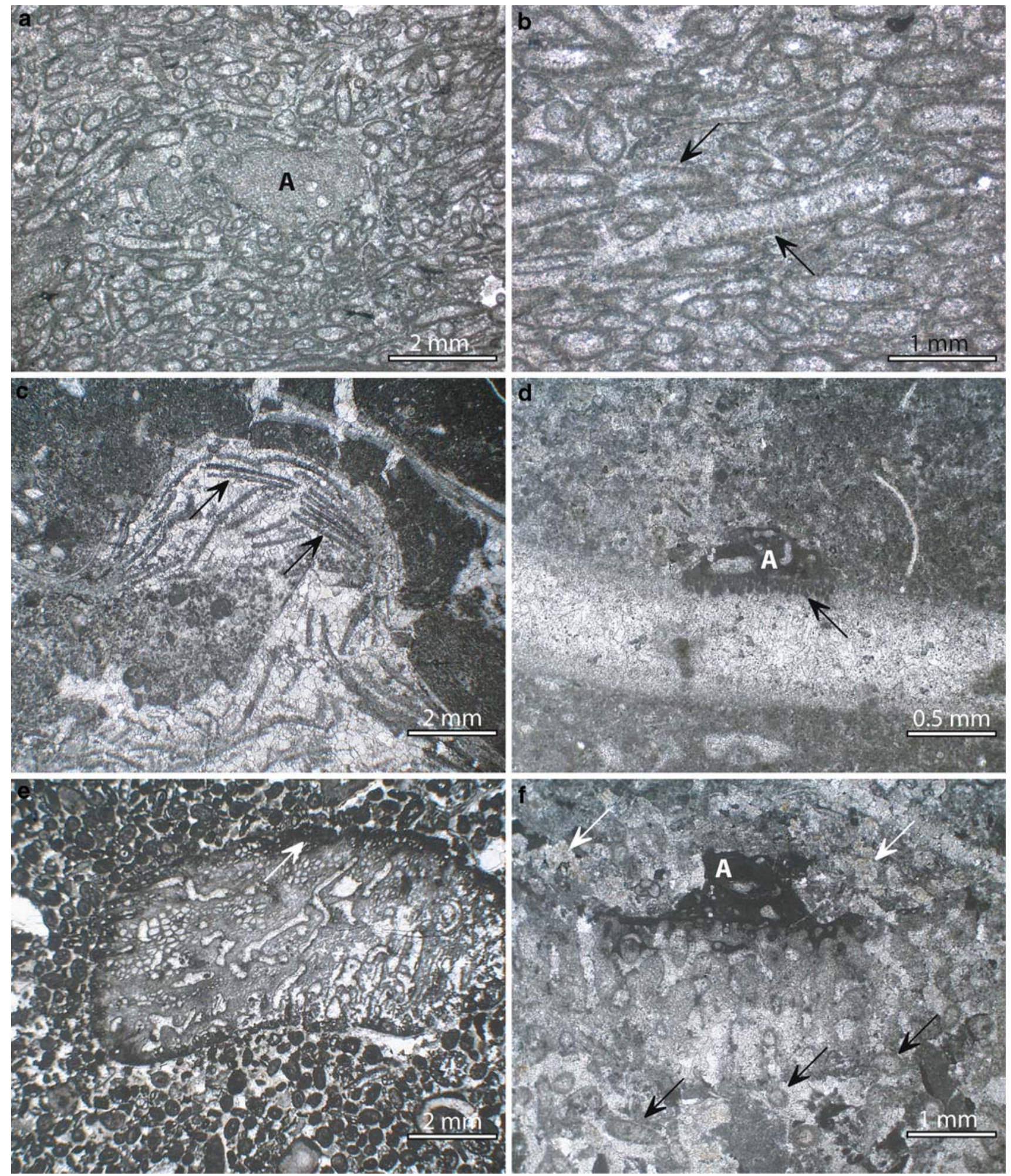

the middle part of a cycle at Carpethøgda ("Section C1", sheet 26-27), where algal bafflestones are associated with solitary and colonial rugose corals and embedded in finegrained sediments of the small-foraminifer facies. The occurrence of phylloid algae is restricted to two horizons in the middle to upper part of sequence 2 of "Section L1" together with the mixed-bioclastic facies. Red algae and beresellid algae fragments also constitute minor component types within the mixed-bioclastic, small-foraminifer and coral reefal facies.

Interpretation: The generally sparse appearance of autochthonous and parautochthonous algal deposits limits a 
4 Fig. 10 Reefal facies: a Algal mound facies ("Section C1", sheet 26): This well-washed bafflestone is nearly exclusively formed of more or less parallel oriented, elongated-cylindrical, beresellid algal thalli, besides of rare red algae fragments $(A)$. The cavities are filled by blocky sparite, reflecting agitated-water conditions. b Algal mound facies ("Section C1", sheet 26): Close-up of beresellid algal thalli, which generally show a poor preservation. While the outer cortex is micritized and equally perforated by pores (arrows), the central medullary layer of the primary aragonitic fragments is completely replaced by blocky sparite. c Algal mound facies ("Section L1", sheet 15): A very poorly preserved accumulation of phylloid algae is characterized by the subparallel, stacked aphanocrystallized rims of single algal thalli (arrows), which are cemented by blocky sparite. The structure is surrounded by dark-gray micritic deposits showing a clotted to peloidal fabric. d Algal mound facies ("Section L1", sheet 13): Close-up of a single phylloid algal plate, which is completely recrystallized. A marginal overgrowth of an encrusting foraminifer $(A)$ preserves the marginal tubules of the outer wall (cortical layer, arrow). e Palaeoaplysina mound facies ("Section L1", sheet 55): A single, well-preserved, sheet-like plate of Palaeoaplysina, partly overgrown by encrusting organisms (white arrow) and embedded in a peloidal grainstone (peloidal facies). The fragment is characterized by a cellular fabric and tubules forming an extended canal system. f Palaeoaplysina mound facies ("Section L1", sheet 55): Cross section of a moderately preserved, single Palaeoaplysina plate, which is marginally encrusted by a foraminifer $(\mathbf{A})$. The skeletal fragment is characterized by a coarse tabular structure filled by clear blocky sparite. Note the Microcodium crystals in the upper part of the picture (white arrows) and the round to oval cross-sections of beresellid algae (black arrows)

detailed reconstruction of their living environment within the investigation area. However, this also implies that the calcareous algae rarely formed larger buildups but rather smaller mounds, or were present only as minor constituents within coral knobs on the platform surface (red and green algae). Fabric, the position within the cycles, and the association with other facies suggest open-marine areas marked by agitated, moderate energy conditions as environment. This reconstruction agrees to the environmental interpretation of Morin et al. (1994) and Hüneke et al. (2001), who suggest a shelf setting at or near at the FWWB for phylloidal and beresellid biostromes.

\section{MFT 15: Palaeoaplysina mound facies}

Within the investigation area, larger bioherms and their flanking deposits are solely formed by the problematic taxon Palaeoaplysina, which has been assigned to sponges, phylloid algae or most likely hydrozoans (Scholle and Ulmer-Scholle 2003). The highly porous and locally strongly dolomitized and silicified deposits consist of smaller, isolated mounds to large, massive bioherms with heights of up to $3 \mathrm{~m}$, constituting boundstones mainly formed of slightly curved, elongated and more or less parallel oriented skeletal plates. These have a thickness of up to $3 \mathrm{~mm}$, reach lengths of several centimeters and often show a characteristic, internal tubular structure (Fig. 10e, f). The upper side of the individual plates is often encrusted by smaller foraminifers or other fine-agglutinating, sessile organisms (Shamovella), forming dark micritic rims, which preserved the porous surface structures, while the original skeletal substance (primary aragonitic) is completely recrystallized. In contrast, the lower side of the plates show no sign of encrustation, which was also observed by Ritter and Morris (1997). The parautochthonous, discontinuously bedded sediments within the interspaces, at the flanks and in the vicinity of the buildups commonly comprise skeletal wackestones (floatstones), packstone or grainstones (rudstones), which are all marked by high amounts of Palaeoaplysina fragments, and locally by Microcodium, peloids, and smaller foraminifers. The facies corresponds to the palaeoaplysinid boundstone and related facies described by Morin et al. (1994). Intergrowths with beresellid green algae have been observed (Fig. 10f).

Occurrence and associations: Besides one minor occurrence within the topmost cycle of "Section L1", rock-forming palaeoaplysinid deposits have been noticed solely at Malte Brunfjellet ("Section MB1"). Here, the occurrence comprises isolated, smaller mounds lined up in certain horizons and larger bioherms, which form, together with their flank deposits, an up to $3 \mathrm{~m}$ thick, massive to discontinuous bedded, lateral persistent stratum (middle to upper part of cycle 11). The deposits are associated with the Microcodium, peloids, mixed-bioclastic and small-foraminifer microfacies.

Interpretation: Hüneke et al. (2001) describe Palaeoaplysina mounds from the overlying Tyrellfjellet Member in central Spitsbergen (Bünsow Land, Boltonbreen) and distinguished a preparation, stabilization, colonization and final cessation stage during the development of large Palaeoaplysina mounds. These stages are closely connected to environmental changes resulting from a generally falling sea level, comprising deeper-marine, sediment-starved conditions below the FWWB, where the initiation of the bioherms took place, to the final emersion of the buildups, causing their termination of growth. The abundance and size of the Palaeoaplysina bioherms at Malte Brunfjellet ("Section MB1") contrast the occurrences of reefal structures within the rest of the study area. The latter can probably be attributed to the palaeogeographic position of the section. This assumption is confirmed by Skaug et al. (1982), Stemmerik et al. (1994) and Pickard et al. (1996), who noticed that Palaeoaplysina bioherms from the overlying Tyrellfjellet Member accumulated along the margins of the fault blocks bordering the Billefjorden Trough (Nordfjorden Block, Ny Friesland Block). The enormous buildups, reaching heights of up to $15 \mathrm{~m}$ created effective barrier systems, which protected lagoonal areas locally marked by restricted, quiet water and possibly temporarily hypersaline, anoxic conditions from more open-marine conditions. Thus, the occurrence of larger bioherms solely at Malte 
Brunfjellet ("Section MB1") probably reflects an area in the vicinity of the platform margin to the adjacent Campbellryggen Basin (Billefjorden Trough) located further to the west.

\section{Discussion}

\section{Depositional environments}

Combining outcrop information with the detailed microfacies studies enables the reconstruction of different facies zones, in which the depositional area of the Ny Friesland Platform can be arranged. These facies zones are characterized by specific depositional environments and thus yield characteristic sediments and biotic associations.

Generally, the Ny Friesland Platform can be described as a flat-topped, low- to moderate-energy carbonate platform, which was dominated by the deposition of rather muddy sediments reflected in the predominance of micritic facies types (i.e., fossiliferous wacke to packstones). Sediments formed under moderate to higher energy conditions like coarser, fossiliferous/ooidal grainstones have been only locally discovered within the platform strata.

\section{Mid-platform}

Open-marine, mid-platform areas were characterized by widespread, low-relief, partly sandy but predominantly muddy flats, which formed below the mean FWWB (Fig. 11). Under quiet-water and low-energy conditions, suspended matter and fine-grained bioclasts accumulated as fossiliferous lime mud on the sea floor. Oxygenated bottom conditions allowed the subsequent bioturbation by sediment feeders. A diverse epifauna mainly consisting of various fusulinid foraminifers, brachiopods, bryozoans and minor echinoderms (crinoids) populated the flats and formed the main source of coarser-grained skeletal fragments and biogens. Coral meadows comprising dense populations of horn-shaped, solitary rugose corals and bryozoans were locally present.

While smaller buildups of colonial corals and calcareous algae were generally rare on the muddy flats, larger Palaeoaplysina bioherms grew along the transitional zone into the adjacent Campbellryggen Basin to the west. These buildups, emerging up to several meters from the sea floor, probably formed conspicuous, wave-resistant barriers during low sea-level stands when the structures ascended above the FWWB (Skaug et al. 1982).

\section{Platform-interior}

With decreasing water depths, the deeper marine mudflats of the mid-platform gradually led into shallow-marine to peritidal flats of the platform interior (Fig. 11). Located generally above the mean FWWB, the sea floor of these areas was generally sandier due to comparatively higher energy conditions resulting in the increased removal of suspended matter (which was mainly transported and accumulated on the muddy flats of the mid-platform below the FWWB) and the deposition of arenitic bioclasts originating from highly diverse associations of carbonate-producing organisms of the platform interior.

Isolated, flat-topped biostromes arose scattered from the sea floor. These small, local elevations were mainly formed by colonial rugose and tabulate corals, chaetetids, coralline red and dasycladalean green algae, which were encrusted by smaller foraminifers and the microproblematicum Shamovella. Vagile benthos, mainly consisting of gastropods, echinoderms, trilobites, ostracodes and foraminifers, populated the otherwise flat areas. Due to the decay of the calcareous skeletons, bioclasts of the various organisms and peloids were locally washed together and winnowed within arenitic sand bars and sandy shoals.

Within more restricted, low-energy areas, extended (tidal) mudflats or lagoons marked by the accumulation of fine-grained suspended material, peloids and a low-diverse fauna, mainly consisting of mollusks and echinoderms, developed. Sporadically, ooidal sand shoals formed due to higher-energy and supersaturated water conditions in waveor tide-agitated nearshore areas.

\section{Sabkha}

In addition to the marine depositional areas of the platform, the development of terrestrial, sabkha-like environments are recorded within temporarily emerged areas of the platform surface (Fig. 11). Within these flats, the emerged limestone strata were affected in varying degrees by desiccation (cracks and brecciation), meteoric alteration (red staining, micritization, recrystallization, dissolution), dolomitization, erosion, reworking and pedogenesis. Locally, the weathering products were redeposited either as laterally restricted, fine-grained hardpans or crusts, or as coarsegrained breccias and lithoclastic conglomerates.

The presence of weakly developed palaeosols and vegetation is reflected by the occurrence of caliche, root traces and Microcodium, possibly resembling salt marshes or mangrove-like vegetation due to the arid to semi-arid climatic conditions. No plant cover is recorded and only the casts of the roots, locally penetrating the uppermost marine strata within single cycles are preserved.

\section{Cycle facies arrangement}

The entire platform strata are marked by a distinct cyclicity formed by stacked sediment packages or sedimentary 


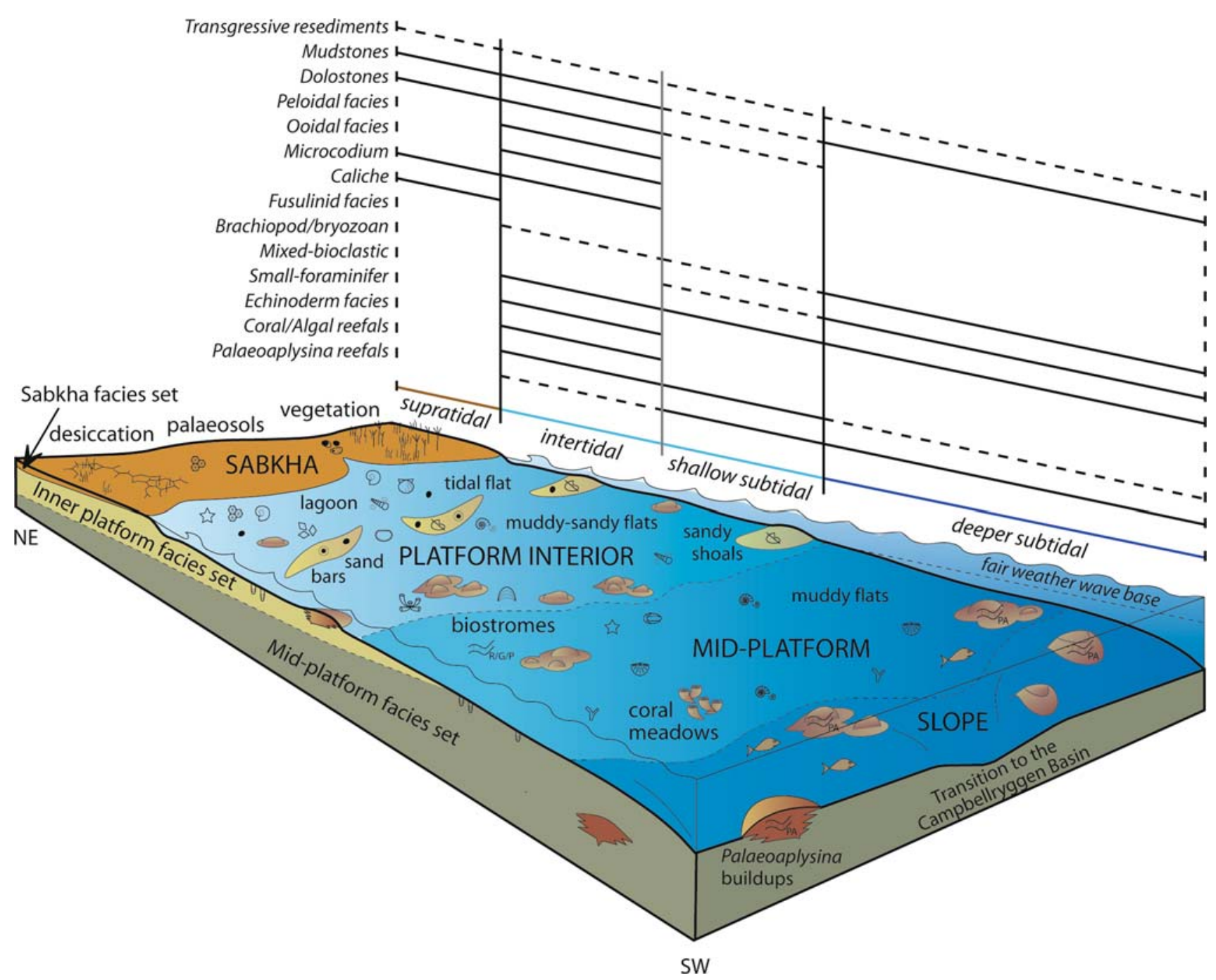

Fig. 11 Schematic reconstruction of the Ny Friesland Platform, showing the occurrence of the defined microfacies types within the different platform areas. Legend in Fig. 12

cycles, which are bounded by distinct discontinuity surfaces. The sedimentary successions of the cycles are arranged into facies sets or units, which comprise specific microfacies associations and thus reflect different depositional areas (mid-platform, inner platform, sabkha) or sedimentary processes (flooding, emersion) of the carbonate platform.

Transgressive facies sets generally comprise basal, only locally occurring deposits within individual cycles (Fig. 12). On the one hand, they consist of gray to brownish, intraformational, coarser-grained limestones (transgressive resediments, MFT 1), which form discontinuous, medium- to thin-bedded horizons with wavy bedding planes. Containing a considerable part of coarse, reworked material from the top of the underlying strata, these lag deposits reflect higher energy conditions connected with the onset of sedimentation during the initial flooding of the platform surface.
Also affiliated to the transgressive facies units are thin, fine-laminated, dark-gray claystones and marls locally interbedding with medium to thin, wavy horizontal-bedded to nodular mudstones (MFT 2) occurring at the base of single sequences. These sediments formed due to the accumulation of fine-grained, suspended particles under quiet-water, probably sediment-starved conditions, which must have prevailed subsequent to the renewed flooding of the platform surface. They reflect a time period before the start-up of the carbonate factory and may also represent a deepening of the depositional area until a certain lag depth (depth needed before water circulation becomes affective enough to allow sediment production; Walker and James 1992) was reached and sediment composition changed due to increasing amounts of bioclasts, which were produced with the reestablishment of the carbonate factory.

Mid-platform facies sets in the lower part of complete cycles (Fig. 12) mainly consist of continuous, darker gray, 


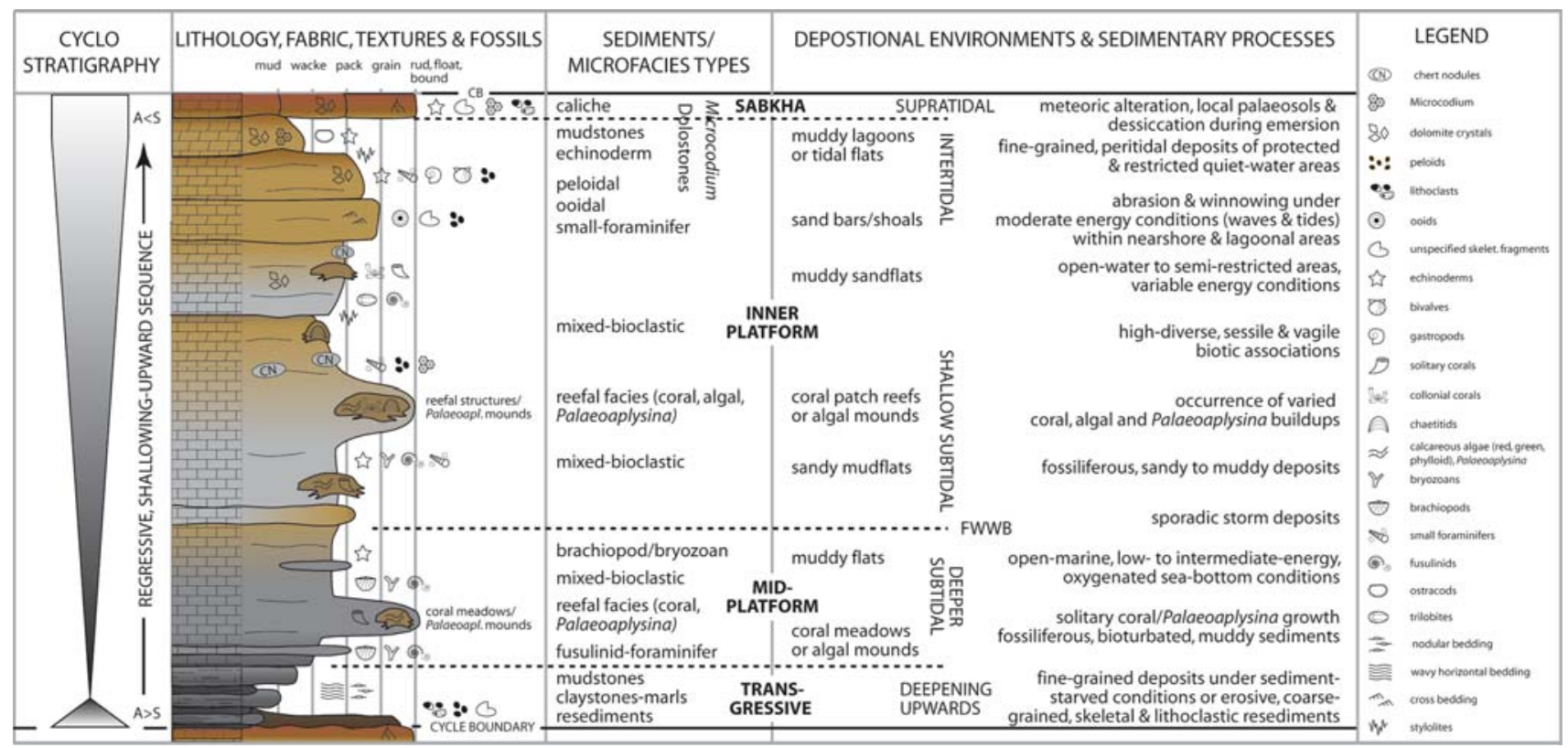

Fig. 12 Composite, ideal parasequence with cyclostratigraphic interpretation and environmental reconstruction. A complete cycle comprises four facies sets (transgressive, mid-platform, inner platform,

slightly wavy, horizontal, thick- to medium-bedded fossiliferous wackestones and minor packstones. The allochthonous sediments comprise the mixed-bioclastic, brachiopod/ bryozoan and fusulinid-foraminifer microfacies types (MFTs 9-11), which vertically and laterally gradually merge into each other. Sporadically occurring, thin horizons or lenses, characterized by the accumulation of skeletal fragments (bioclastic packstones) may represent storm deposits. Laterally restricted "coral meadows" marked by the enrichments of solitary rugose corals, bryozoans and their coarse-grained debris (MFT 13, coral floatstones), are also locally included within these sediments. The deposits probably formed below the mean FWWB when sea level was highest and show a gradual transition into the innerplatform facies sets by a general increase of the bed thickness and/or the proportion and diversity of skeletal fragments upwards.

Inner-platform facies sets representing the shallowmarine to peritidal areas (lagoons, (tidal) flats and nearshore areas) of the platform interior are most common and present within all cycles of the strata. They consist of very thick- to medium-bedded, light-gray to light-brownish or multicolored limestone and dolomite beds, often separated by stylolites. Allochthonous deposits are mainly formed of fossiliferous packstones to wackestones with minor grainstones and mudstones comprising the mudstone, peloidal, ooidal, mixed-bioclastic, small-foraminifer and echinoderm microfacies types (Fig. 12). Embedded within these deposits are common to occasional occurring, autochthonous coral, algal and palaeoaplysina buildups (MFTs 13-15). A sabkha) characterized by specific microfacies associations ( $A$ accommodation space, $S$ sediment supply)

considerable part of the limestones are replaced by dolomites (MFT 3). These deposits probably formed during general decreasing water depth, when the increase of accommodation space was less than the rate of sediment supply of the carbonate factory.

At the top of the cycles, sabkha facies units consisting of multicolored, discontinuous, thin horizons or lenses of strongly altered platform strata are locally present (Fig. 12). The sediments, comprising the caliche and/or Microcodium microfacies (MFTs 6, 7) and dolostones (MFT 3) show sharp, wavy horizontal to irregular subsurfaces or are bounded by stylolites. The only locally occurring cap rocks of individual cycles reflect supratidal, terrestrial conditions, which prevailed due to the emersion of extended parts of the platform surface during sea-level lowstands. Within these areas, the carbonate factory was shut-down and the uppermost marine strata were subjected to alteration and erosion. Weathering products, mainly consisting of distinct red, partly brecciated mudstones and litho to bioclastic pack to rudstones were redeposited within restricted areas. In addition, the sediments were to a varying degree superimposed by pedogenesis, forming local, weakly developed palaeosols.

\section{Cycle stacking pattern and cyclostratigraphy}

The pronounced cyclicity of the Late Carboniferous platform strata has been described from coeval marine platform successions all over the world. On the northern hemisphere, comparable successions have been studied within the North 
American Midcontinent by Boardman and Heckel (1989), West et al. (1997) and Olszewski and Patzkowsky (2003), and in the Sverdrup Basin of the Canadian Arctic by Beauchamp (1994), Morin et al. (1994) and Beauchamp and Desrochers (1997). Håkansson and Stemmerik (1989), Cecchi et al. (1995), Stemmerik et al. (1995), Stemmerik and Worsley (1995), Stemmerik (1997) and Samuelsberg and Pickard (1999) presented similar features in the strata of the Wandel Sea Basin from northern Greenland and the Barents Sea. Information from the Russian Moscow Basin is delivered by Alekseev et al. (1996), Kabanov (2003) and Baranova and Kabanov (2003).

Most of the above-mentioned authors suggest that the formation of the stacked cycles within the marine strata is caused by synchronous, global eustatic sea-level changes of Milankovich periodicities (Ross and Ross 1985). Driven by changes in the ice volume associated with the southern Gondwana Land glaciation (Visean, Sakmarian), such glacio-eustatic, high-frequent sea-level fluctuations are supposed to have reached amplitudes of more that $100 \mathrm{~m}$ (Golonka and Ford 2000; Soreghan and Giles 1999; Joachimski et al. 2006; Tucker et al. 1993).

Within the strata of the Ny Friesland Platform these glacio-eustatic sea-level fluctuations are represented within the stacked successions, which are interpreted as shallowingupward cycles, as they reflect a general shallowing of the depositional area. A deepening of the depositional environment may be recorded within the only locally occurring, transgressive facies sets at the base of single cycles.

The bounding discontinuity surfaces of the stacked shallowing-upward cycles are defined by an abrupt facies change between the lower and the overlying cycle and reflect a break in marine sedimentation due to the emersion of the uppermost strata of the carbonate platform within extended areas. In a cyclostratigraphic view, the surfaces represent transgressive surfaces or marine flooding surfaces as they document the onset of marine sedimentation with the renewed flooding of the platform surface and subsequent increasing water depths due to a relative rise in sea level. Thus, the term parasequence (after Van Wagoner et al. 1990) can be applied to the shallowing-upward cycles since it describes genetically related beds or bed sets (in this case the transgressive, mid-platform, inner-platform and sabkha facies sets) bounded by marine flooding surfaces.

Based on biostratigraphic data by means of conodonts and fusulinid foraminifers, Pickard et al. (1996) indicate a Late Moscovian (Kashirian to Myachkovian) to Early/Middle Kasimovian age for the cyclic carbonate platform strata in central Spitsbergen. This depositional time interval agrees to the age determinations within the individual vertical sections.

Based on preliminary biostratigraphic results from several sections (e.g., cycles 1-8 in "Section L1" represent
Late Moscovian to Middle Kasimovian spanning approx. $3 \mathrm{Ma}$ ) the number of cycles fit closely to the number of major cyclothems from North American Midcontinent and Moscow Basin, which are regarded as eccentricity cycles (400 ka; Heckel 2006; Heckel et al. 2007).

Considering the entire platform strata, systematic changes of the overall stacking pattern become apparent. Upwards, the successive cycles generally decrease in thickness (Fig. 4) and simultaneously show changes in their internal structure. Hence, the mid-shelf facies sets strongly decrease in thickness and are not present any more within the cycles of the upper platform strata. In field, these systematic changes are often geomorphologically emphasized, as the generally more muddy mid-shelf deposits are generally less resistant against weathering compared to the arenitic limestones and dolostones of the platform interior. As a result, escarpments comprising the platform strata (Fig. 5a, b, f) often show a terraced, step-like appearance formed by the stacked sequences within the lower parts of the platform strata. Further upwards, this geomorphological feature gradually disappears, as the less resistant mid-shelf facies sets are missing and the platform strata are more consistent.

The systematic changes in cycle thickness and their internal composition could result from continuously decreasing amplitudes of the glacio-eustatic sea-level changes during the platform development. Assuming an onset of the glaciation within the Serpukhovian and a first glacial maximum during the early Moscovian, a subsequent, temporary slowdown of the glaciation would have resulted in progressively smaller sea-level fluctuations during the later course of the Pennsylvanian (pers. com. W. Buggisch).

Another explanation for the systematic changes of the nature of the cycles is given by Coe (2005), when 4thorder, glacio-eustatic sea-level fluctuations superimpose a late sea-level highstand of lower level (Fig. 13a). Due to the flattening of the primary sea-level curve, the increase in accommodation space for each successive parasequence is less than the constant rate of sediment supply. This development results in the platform progradation as newly produced sediments are transported form the platform surface into the adjacent basin, where accommodation space is still available (Fig. 13b). Accordingly, the upper part of the entire platform strata could be described as a progradational parasequence set.

\section{Summary}

The fossiliferous strata of the Late Carboniferous Ny Friesland Platform in eastern Spitsbergen are marked by a pronounced cyclicity formed by stacked parasequences with thicknesses of up to several meters. These are characterized 


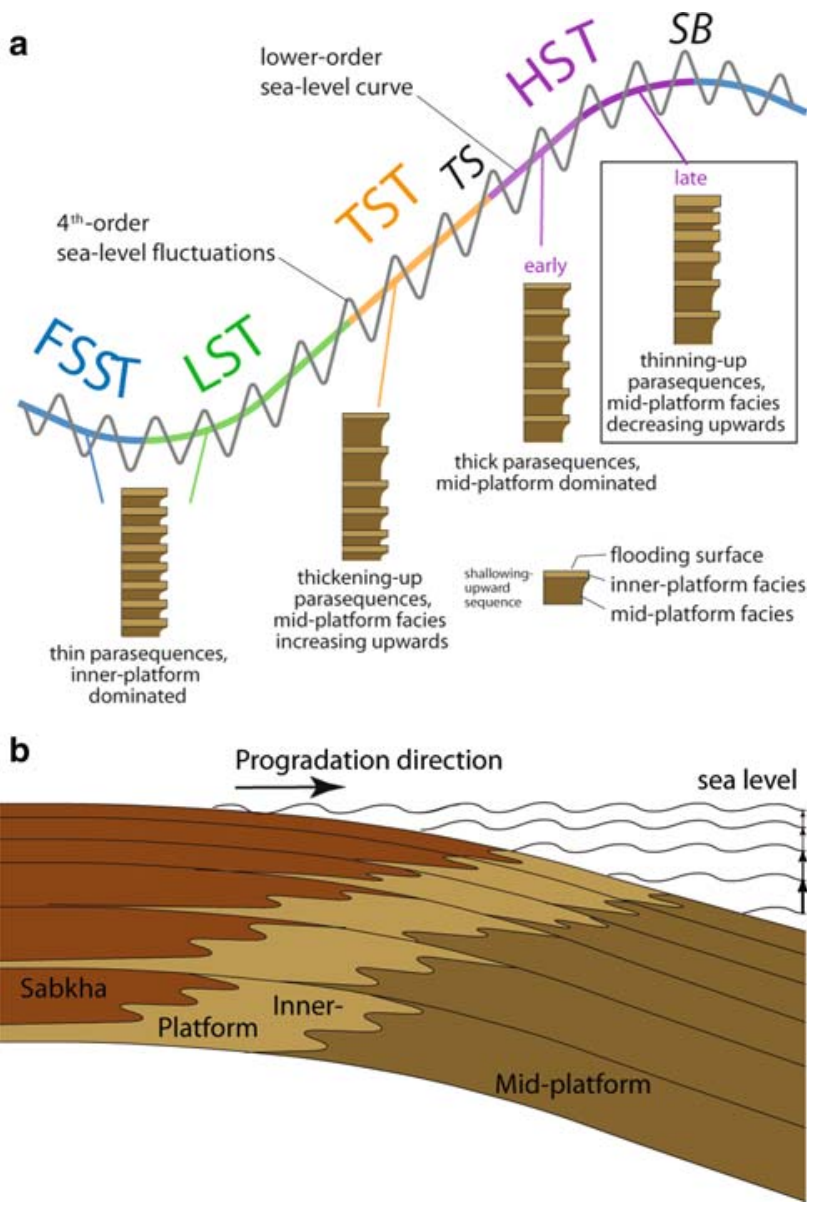

Fig. 13 Idealized stacking pattern of shallow-marine parasequences of a carbonate platform. a The stacking pattern of the Ny Friesland Platform is in accordance to a late highstand system tract. $S B$ Sequence boundary; TS Transgressive surface. b Accumulation geometry of a carbonate platform under a decreasing relative sea-level rise during a late sea-level highstand (modified after Coe 2005)

by successions of defined (micro-) facies sets reflecting specific depositional areas (mid-platform, platform, interior, sabkha) and sedimentary processes (flooding, emersion) of the carbonate platform.

At the base of individual cycles, locally occurring transgressive facies sets comprise intraformational, coarsergrained resediments (lag deposits) or fine-grained, condensed sediments (mudstones, marls and claystones), deposited during or shortly after the initial flooding of the platform surface.

These basal sediments are followed by mid-platform facies sets mainly consisting of thick- to medium-bedded, fossiliferous wackestones dominated by brachiopods, bryozoans or fusulinid foraminifers, locally embedding lateral restricted coral meadows of horn-shaped, solitary, rugose corals. The sediments formed under quiet-water, openmarine, oxygenated conditions on submarine, muddy flats below the mean fair-weather wave base, when water depths were highest.
Upwards in strata, the sediments grade into very thickto medium-bedded dolomite and limestone beds, which constitute the most common, inner-platform facies sets. These deposits, marked by the common occurrence of stylolites are mainly formed of highly diverse, fossiliferous packstones to wackestones (with minor grainstones and mudstones) comprising fragments of brachiopods, bryozoans, echinoderms, foraminifers, various calcareous algae (red algae, green algae, phylloid algae), chaetetids, colonial rugose and tabulate corals, Palaeoaplysina, mollusks as well as abiotic components like ooids and peloids in varying amounts. The allochthonous sediments embed small, isolated biostromes (bafflestones) formed by chaetetids, calcareous algae and colonial rugose and/or tabulate corals as well as larger Palaeoaplysina mounds (framestones) in marginal platform positions. The various sediments reflect the presence of sandy to muddy flats formed under low- to moderate-energy and open- to restricted-water conditions within shallow marine to intertidal platform areas.

At the top of the recurrent cycles, sabkha facies sets consisting of multicolored, laterally discontinuous, thin- to medium-bedded Microcodium or caliche horizons or subaerially altered marine strata (peloidal, litho to bioclastic pack to grainstones and rudstones) are locally present. These capping beds reflect a break in marine sedimentation and the presence of terrestrial, low-relief sabkha areas, which formed under arid to semi-arid climatic conditions during the emersion of the platform surface.

As the facies-set successions of the individual parasequences generally reflect a shallowing of the depositional area, the parasequences are interpreted as shallowingupwards cycles, bounded by distinct discontinuity (marine flooding) surfaces due to the emersion and subsequent flooding of the carbonate platform top.

The cyclicity of the platform strata is the result of global, glacio-eustatic, high-frequent and high-amplitudinal sealevel fluctuations caused by volume changes of polar ice caps during the Gondwana Land glaciation and probably reflect Milankovich eccentricity periodicities of 100 $400 \mathrm{ka}$.

An overall shallowing trend is reflected by systematic changes in cycle thickness (thinning up) and in the internal structure of the single cycles (changes in the proportion of mid-platform and inner-platform facies sets) upwards in strata. This overall stacking pattern displays a continuous decrease in accommodation space with each successive parasequence at the end of a late sea-level highstand, causing the progradation of the Ny Friesland Platform into the neighboring Campbellryggen Basin.

Deposited with a major transgressive surface on underlying basement rocks or Late Carboniferous terrestrial red bed successions, the parasequence set of the Ny Friesland Platform thus comprises the highstand system tract of the 
second (Moscovian to Gzhelian) of altogether four major transgressive-regressive cycles (Stemmerik et al. 1995; Pickard et al. 1996; Samuelsberg and Pickard 1999; Hüneke et al. 2001) recorded in the Late Paleozoic superstratum of Svalbard and the Barents Sea.

Acknowledgments We are grateful to Winfried Dallmann for initiating the investigations as a part of the Norwegian Polar Institute's geological mapping program. The organization and logistics department of the Norwegian Polar Institute is also thanked for the preparation and support during the field campaigns on Svalbard. Ralf Bätzel, technician at the University of Bremen is thanked for the excellent preparation of numerous thin-sections forming the basis of the microfacies investigations. Barbara Reinike, Peter Hülse, and Karin Behrend, who wrote their master, respectively, bachelor theses on the platform strata, contributed much information and greatly improved the understanding of the platform sedimentology and structure. Werner Buggisch and Vladimir Davydov are acknowledged for reviewing the manuscript.

\section{References}

Alekseev AS, Gorbachik TN, Smirnova SB, Bragin NY (1996) Age of the Paramonovo Formation (the Albian of the Russian platform) and global transgressive-regressive cycles of the Cretaceous. Stratigr Geol Correl 4:341-361

Baranova DV, Kabanov PB (2003) Facies distribution of fusulinoid genera in the Myachkovian (Upper Carboniferous, Upper Moscovian) of Southern Moscow Region. Rivista Italiana di Paleontologica e Stratigrafia 109:225-239

Beauchamp B (1994) Permian climatic cooling in the Canadian Arctic. In: Klein GD (ed) Pangea: paleoclimate, tectonics, and sedimentation during accretion, zenith, and breakup of a supercontinent. Geol Soc Am, 11(1):229-246

Beauchamp B, Harrison JC, Henderson CM (1989) Upper Paleozoic stratigraphy and basin analysis of the Sverdrup Basin, Canadian Arctic Archipelago: Part 1 and 2. Current research, Part G, Geol Sur Can, paper 89-1G, pp 105-124

Beauchamp B, Desrochers A (1997) Permian warm- to very cold-water carbonates and cherts in northwest Pangea. In: James NP, Clarke JAD (eds) Cool-water carbonates. SEPM, Tulsa, pp 327-347

Behrend K (2007) Mikrofaziesanalyse der oberkarbonen Malte Brunfjellet Formation auf Spitzbergen. Bachelor Thesis, University Bremen, Germany

Birkenmajer K, Czarniecki S (1960) Stratigraphy of marine Carboniferous and Permian deposits in Hornsund (Vestspitsbergen), based on Brachiopods. Bull Pol Acad Sci. Earth Sci 8:203-209

Birkenmajer K (1964) Devonian, Carboniferous and Permian formations of Hornsund, Vestspitsbergen. Studia Geologica Polonica 11:47-123

Boardman DR, Heckel PH (1989) Glacial-eustatic sea-level curve for early Late Pennsylvanian sequence in north-central Texas and biostratigraphic correlation with curve for midcontinent North America. Geology 17:802-805

Cecchi C, Markello J, Waite L (1995) Sequence stratigraphy architecture of Carboniferous-Permian sedimentary systems of the Norwegian Barents Sea with comparison to coeval systems of the USA. In: Steel RJ, Felt VL, Johannesen EP, Mathieu C (eds) Sequence stratigraphy on the Northwest European Margin. Elsevier, Amsterdam, pp 545-569

Coe AL (2005) The sedimentary record of sea-level change. The Open University, Cambridge

Cutbill JL (1968) Carboniferous and Permian stratigraphy of Ny Friesland, Spitsbergen. Norsk Polarinstitutt Årbok 1966:12-24
Cutbill JL, Challinor A (1965) Revision of the stratigraphical scheme for the Carboniferous and Permian rocks of Spitsbergen and Bjørnøya. Geol Mag 102:418-439

Dallmann WK (1993) Notes on the stratigraphy, extent and tectonic implications of the Minkinfjellet Basin, Middle Carboniferous of central Spitsbergen. Polar Res 12:153-160

Dallmann WK (1999) Lithostratigraphic lexicon of Svalbard. Norwegian Polar Institute, Troms $\varnothing$

Flügel E (2004) Microfacies of carbonate rocks. Springer, Berlin Heidelberg New York

Forbes CL, Harland WB, Hughes NF (1958) Palaeontological evidence for the age of the Carboniferous and Permian rocks of Central Vestspitsbergen. Geol Mag 95:463-490

Forbes CL (1960) Carboniferous and Permian Fusulinidae from Spitsbergen. Palaeontology 2:210-225

Gee ER, Harland WB, McWhae JRH (1952) Geology of Central Vestspitsbergen: Part I. Review of the geology of Spitsbergen, with special reference to Central Vestspitsbergen. Part II. Carboniferous to Lower Permian of Billefjorden. Trans R Soc Edinb 62:299_ 356

Gjelberg JG, Steel RJ (1981) An outline of lower-middle Carboniferous sedimentation on Svalbard: effects of tectonic, climatic and sea level changes in rift basin sequences. In: Kerr JW, Fergusson AJ (eds) Geology of the North Atlantic borderlands. Can Soc Petrol Geol, Calgary, pp 543-561

Golonka J, Ford D (2000) Pangean (Late Carboniferous-Middle Jurassic) paleoenvironment and lithofacies. Palaeogeogr Palaeoclimatol Palaeoecol 161:1-34

Gradstein F, Ogg J, Smith A (2004) A geologic time scale 2004. University Press, Cambridge

Halverson GP, Maloof AC, Hoffman PF (2004) The Marinoan glaciation (Neoproterozoic) in northeast Svalbard. Basin Res 16:297-324

Harland (1997) The geology of Svalbard. Geol Soc Lond

Heckel PH (2006) Latest calibration of Middle to Late Pennsylvanian time scale using succession of Midcontinent cyclothems. Newsl Carboniferous Stratigr 24:35-39

Heckel PH, Alekseev AS, Barrick JE, Boardman DR, Goreva NV, Nemyrovska TI (2007) Cyclothem ("digital”) correlation and biostratigraphy across the global Moscovian-Kasimovian-Gzhelian stage boundary interval (Middle-Upper Pennsylvanian) in North America and eastern Europe. Geology 35:607-610

Hülse P (2007) Eustatic sea-level changes on a Late Carboniferous carbonate platform in north-eastern Spitsbergen: facies analysis on shallowing-upward cycles. Master Thesis, University München, Germany

Hüneke H, Joachimski M, Buggisch W, Lützner H (2001) Marine carbonate facies in response to climate and nutrient level: the Upper Carboniferous and Permian of Central Spitsbergen (Svalbard). Facies 45:93-136

Håkansson E, Stemmerik L (1989) Wandel Sea basin-a new synthesis of the late Paleozoic to Tertiary accumulation in North Greenland. Geology 17:683-686

Joachimski MM, von Bitter PH, Buggisch W (2006) Constraints on Pennsylvanian glacioeustatic sea-level changes using oxygen isotopes of conodont apatite. Geology 34:277-280

Johannessen EP, Steel RJ (1992) Mid-Carboniferous extension and rift-infill sequences in the Billefjorden Trough, Svalbard. Nor Geol Tidsskr 72:35-48

Kabanov P (2003) The upper Moscovian and basal Kasimovian (Pennsylvanian) of central European Russia: facies, subaerial exposures and depositional model. Facies 49:243-270

Kabanov P, Anadón P, Krumbein WE (2008) Microcodium: an extensive review and a proposed non-rhizogenic biologically induced origin for its formation. Sediment Geol 205:79-99

Klappa CF (1978) Biolithogenesis of Microcodium: elucidation. Sedimentology 25:489-522 
Lauritzen Ø (1981a) Investigations of Carboniferous and Permian sediments in Svalbard I. The development of the Gipshuken Formation (Lower Permian) at Trollfuglfjella in Central Spitsbergen, Svalbard. Nor Polarinst Skr 176:1-22

Lauritzen $\emptyset$ (1981b) Investigations of Carboniferous and Permian sediments in Svalbard II. The Carboniferous and Permian stratigraphy of the Wahlenbergfjorden area, Nordaustlandet, Svalbard. Nor Polarinst Skr 176:23-44

Lauritzen $\varnothing$, Worsley D (1975) Observations on the Upper Palaeozoic stratigraphy of the Ny Friesland area. Norsk Polarinstitutt Årbok 1973:41-51

Leppig U, Forke HC, Montenari M, Fohrer B (2005) A three- and twodimensional documentation of structural elements in schwagerinids (superfamily Fusulinoidea) exemplified by silicified material from the Upper Carboniferous of the Carnic Alps (Austria/Italy): a comparison with verbeekinoideans and alveolinids. Facies 51:541-553

Leutenegger S (1984) Symbiosis in benthic Foraminifera-specificity and host adaptation. J Foramin Res 14:16-35

Lønøy A (1981) Fasies analyse av undre permiske karbonater i Tyrrellfjellet Ledd av Nordenskiöldbreen Formasjonen, Billefjordområdet, Spitsbergen. Master Thesis, University of Bergen, Norway

Lønøy A (1995) A mid-Carboniferous, carbonate-dominated platform, central Spitsbergen. Nor Geol Tidsskr 75:48-63

McWhae JRH (1953) The Carboniferous breccias of Billefjorden, Vestspitsbergen. Geol Mag 90:287-298

Miloslavskij MJ, Birjukov AS, Šlënskij SN, Dallmann WK (1998) Geological map D8G, Negribreen. Norsk Polarinstitutt, Oslo

Morin J, Desrochers A, Beauchamp O, Beauchamp B (1994) Facies analysis of Lower Permian platform carbonates, Sverdrup Basin, Canadian Arctic Archipelago. Facies 31:105-130

Nathorst AG (1910) Beiträge zur Geologie der Bäreninsel, Spitzbergens und des König-Karl-Landes. Bulletin Geologiska Institutionen Universitetet i Uppsala 10:261-416

Nilsson I (1993) Upper Paleozoic fusulinid stratigraphy of the Barents Shelf and surrounding areas. PhD Thesis, University of Troms $\varnothing$, Norway

Olaussen S (1982) Description and interpretation of two sedimentary sequences of the Lower/Middle Carboniferous from Nordaustlandet and Lomfjorden (Ismåsestranda and Bivrastfonna). Rapport 86.09, Statoil

Olszewski TD, Patzkowsky ME (2003) From cyclothems to sequences: the record of eustasy and climate on an icehouse epeiric platform (Pennsylvanian-Permian, North American Midcontinent). J Sediment Res 73:15-30

Pickard NAH, Eilertsen F, Hanken N-M, Johansen TA, Lønøy A, Nakrem HA, Nilsson I, Samuelsberg TG, Somerville ID (1996) Stratigraphic framework of Upper Carboniferous (MoscovianKasimovian) strata in Bünsow Land, central Spitsbergen: palaeogeographic implications. Nor Geol Tidsskr 76:169-185

Reinicke B (2006) Facies analysis in the shallow marine limestone strata of NE Spitsbergen (Gipsdalen Group, Late Carboniferous). Master Thesis, University Freiburg, Germany

Ritter SM, Morris TH (1997) Oldest and lowest latitudinal occurrence of Palaeoaplysina: Middle Pennsylvanian Ely Limestone, Burbank Hills, Utah. Palaios 12:397-401

Ross CA (1972) Paleobiological analysis of fusulinacean (Foraminiferida) shell morphology. J Paleontol 46:719-728

Ross CA, Ross JRP (1985) Late Palaeozoic depositional sequences are synchronous and worldwide. Geology 13:194-197

Ross CA, Ross JRP (1988) Late Paleozoic transgressive-regressive deposition. In: Wilgus CK, Hastings BS, Kendall CG, Posamentier HW, Ross CA, Van Wagoner JC (eds) Sea-level changes-an integrated approach, vol 42. SEPM Spec Publ, pp 227-247

Samuelsberg T, Pickard N (1999) Upper Carboniferous to Lower Permian transgressive-regressive sequences of central Spitsbergen, Arctic Norway. Geol J 34:393-411
Scholle PA, Bebout DG, Moore CH (1983) Carbonate depositional environments. AAPG Memoir 33, Tulsa

Scholle PA, Ulmer-Scholle DS (2003) A color guide to the petrography of carbonate rocks: grains, textures, porosity, diagenesis. AAPG Memoir 77, Tulsa

Scotese CR, McKerrow WS (1990) Revised world maps and introduction. In: McKerrow WS, Scotese CR (eds) Palaeozoic palaeogeography and biogeography. Geol Soc, pp 1-21

Skaug M, Dons C, Lauritzen Ø, Worsley D (1982) Lower Permian palaeoaplysinid bioherms and associated sediments from central Spitsbergen. Polar Res 2:57-75

Soreghan GS, Giles KA (1999) Amplitudes of Late Pennsylvanian glacioeustasy. Geology 27:255-258

Steel RJ, Worsley D (1984) Svalbard's post-Caledonian strata-an atlas of sedimentational patterns and palaeogeographic evolution. In: Spencer AM, Holter E, Johnson SO, Mørk A, Nysæther E, Songstad P, Spinnangr Å (eds) Petroleum geology of the North European margin. Graham \& Trotman Ltd., London, pp 109-135

Stemmerik L (1997) Permian (Artinskian-Kazanian) cool-water carbonates in north Greenland, Svalbard, and the western Barents Sea. In: James NP, Clarke JAD (eds) Cool-water carbonates. SEPM, Tulsa, pp 349-364

Stemmerik L, Larson P, Larssen G, Mørk A, Simonsen B (1994) Depositional evolution of Lower Permian Palaeoaplysina build-ups, Kapp Duner formation, Bjørnoya, Arctic Norway. Sediment Geol 92:161-174

Stemmerik L, Nilsson I, Elvebakk G (1995) Gzelian-Asselian depositional sequences in the western Barents Sea and Greenland. In: Steel RJ, Felt VL, Johannesen EP, Mathieu C (eds) Sequence stratigraphy on the Northwest European Margin. Elsevier, Amsterdam, pp 529-544

Stemmerik L, Worsley D (1995) Permian history of the Barents Shelf area. In: Scholle PA, Peryt TM, Ulmer-Scholle DS (eds) The Permian of Northern Pangea. Sedimentary basins and economic resources. Springer, Berlin Heidelberg New York, pp 81-97

Stevens C-H (1969) Water depth control of fusulinid distribution. Lethaia 2:121-132

Sundsbø G (1982) Facies analysis of the Late Carboniferous and Early Permian carbonates in the Billefjorden area, Spitsbergen. Unpublished Master Thesis, University of Bergen, Norway

Tucker ME, Calvet F, Hunt D (1993) Sequence stratigraphy of carbonate ramps: system tracts, models and application to the Muschelkalk carbonate platforms of eastern Spain. In: Posamentier HW, Summerhayes CP, Haq BU, Allen GP (eds) Sequence stratigraphy and facies associations. International Association of Sedimentologists. Blackwell, Oxford, pp 397-415

Vachard D, Munnecke A, Servais T (2004) New SEM observations of keriothecal walls: implications for the evolution of Fusulinida. J Foramin Res 34:232-242

Veevers J, Powell CM (1987) Late Paleozoic glacial episodes in Gondwanaland reflected in transgressive-regressive depositional sequences in Euramerica. Geol Soc Am Bull 98:475-487

Van Wagoner JC, Mitchum RM, Campion KM, Rahmanian VD (1990) Siliciclastic sequence stratigraphy in well logs, cores, and outcrops: concepts for high-resolution correlation of time and facies. AAPG Methods in Exploration Series 7:1-55

Walker RG, James NP (1992) Facies models: response to sea level change. Geological association of Canada. Love Printing Service Ltd, Ontario

West RR, Archer AW, Miller KB (1997) The role of climate in stratigraphic patterns exhibited by late Palaeozoic rocks exposed in Kansas. Palaeogeogr, Palaeoclimatol Palaeoecol 128:1-16

Worsley D, Aga OJ, Dalland A, Elverhøi A, Thon A (1986) The geological history of Svalbard-evolution of an arctic archipelago. Statoil, Stavanger 